\title{
A secondary organic aerosol formation model considering successive oxidation aging and kinetic condensation of organic compounds: global scale implications
}

\author{
F. Yu \\ Atmospheric Sciences Research Center, State University of New York, Albany, New York, USA
}

Received: 25 July 2010 - Published in Atmos. Chem. Phys. Discuss.: 23 August 2010

Revised: 20 January 2011 - Accepted: 29 January 2011 - Published: 8 February 2011

\begin{abstract}
The widely used two-product secondary organic aerosol (SOA) formation model has been extended in this study to consider the volatility changes of secondary organic gases (SOG) arising from the aging process as well as the kinetic condensation of low volatile SOG (LV-SOG). In addition to semi-volatile SOG (SV-SOG) with saturation vapor pressure at $290 \mathrm{~K}\left(C_{290}^{*}\right)$ in the range of $\sim 3 \mathrm{ppt}-3 \mathrm{ppb}$ and medium-volatile SOG (MV-SOG) with $C_{290}^{*}$ in the range of $\sim 0.3-300 \mathrm{ppb}$, we add a third component representing LVSOG with $C_{290}^{*}$ below $\sim 3$ ppt and design a scheme to transfer MV-SOG to SV-SOG and SV-SOG to LV-SOG associated with oxidation aging. This extended SOA formation model has been implemented in a global aerosol model (GEOSChem) and the co-condensation of $\mathrm{H}_{2} \mathrm{SO}_{4}$ and LV-SOG on pre-existing particles is explicitly simulated. We show that, over many parts of the continents, LV-SOG concentrations are generally a factor of $\sim 2-20$ higher than those of $\mathrm{H}_{2} \mathrm{SO}_{4}$ and the kinetic condensation of LV-SOG significantly enhances particle growth rates. Comparisons of the simulated and observed evolution of particle size distributions at a boreal forest site (Hyytiälä, Finland) clearly show that LVSOG condensation is critical in order to bring the simulations closer to the observations. With the new SOA formation scheme, annual mean SOA mass increases by a factor of 2-10 in many parts of the boundary layer and reaches above $0.5 \mu \mathrm{g} \mathrm{m}^{-3}$ in most parts of the main continents, improving the agreement with aerosol mass spectrometer (AMS) SOA measurements. While the new scheme generally decreases the concentration of condensation nuclei larger than $10 \mathrm{~nm}$ by $3-30 \%$ in the lower boundary layer as a result of enhanced
\end{abstract}

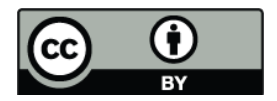

Correspondence to: $\mathrm{F}$. Yu (yfq@asrc.cestm.albany.edu) surface area and reduced nucleation rates, it substantially increases the concentration of cloud condensation nuclei at a water supersaturation ratio of $0.2 \%$, ranging from $\sim 5-20 \%$ over a large fraction of oceans and high latitude continents to more than $50 \%$ over some parts of South America, Australia, and Indonesia. Our study highlights the importance for global aerosol models to explicitly account for the oxidation aging of SOGs and their contribution to particle growth.

\section{Introduction}

Particles in the atmosphere have important impacts on regional to global climate, air quality, and human health. The significance of these impacts depends strongly on the particle properties including concentration, size, composition, hygroscopic parameter, and mixing state. One major uncertainty in present regional and global aerosol simulations is associated with the contribution of secondary organic aerosol (SOA) to particle growth, size, and mass. Formation and the subsequent growth of secondary particles observed frequently in various parts of the globe (Kulmala et al., 2004; Yu et al., 2008) are an important source of atmospheric aerosols. While the involvement of $\mathrm{H}_{2} \mathrm{SO}_{4}$ in atmospheric particle formation is well established, many field measurements indicate that the growth rates of nucleated particles are commonly a factor of $\sim 2-20$ higher than can be explained by $\mathrm{H}_{2} \mathrm{SO}_{4}$ vapor condensation alone (e.g., Kuang et al., 2010). The condensation of low volatile organic species, which is poorly represented in current aerosol models, is likely to dominate the growth rate of freshly nucleated particles in many regions. Particle composition measurements indicate that organic aerosol (OA) makes up $\sim 20-90 \%$ of submicron

Published by Copernicus Publications on behalf of the European Geosciences Union. 
particulate mass (Zhang et al., 2007) and SOA accounts for a large fraction $(\sim 72 \pm 21 \%)$ of these OA masses at many locations around the globe (Jimenez et al., 2009). Atmospheric chemical transport models have been known to underestimate atmospheric OA and SOA mass, in some cases by a factor of 10 or more (Heald et al., 2005; Volkamer et al., 2006). In addition to uncertainties in the emission inventories of SOA precursors and laboratory data of SOA yields, the poor representation of SOA formation in the models could also lead to model under-prediction (Hallquist et al., 2009; Pankow and Barsanti, 2009).

The chemical and physical processes associated with SOA formation are very complex (Kroll and Seinfeld, 2008; Hallquist et al., 2009) because of the large amount of different organic compounds involved. Present model predictions of atmospheric SOA formation are largely built upon the theoretical foundations on organic gas/particle partitioning developed by Pankow in the 1990s (Pankow, 1994) and extended by Odum et al. to SOA formation (Odum et al., 1996). According to the theory, partitioning of each semi-volatile compound between secondary organic gas (SOG) and aerosol (SOA) phases can be described by an equilibrium partitioning coefficient $K_{p}\left(\mathrm{~m}^{3} \mu \mathrm{g}^{-1}\right)$, or equivalently (Donahue et al., 2006) its inverse, the effective saturation vapor concentration, $C^{*}\left(\mu \mathrm{g} \mathrm{m}^{-3}\right)$,

$$
\frac{C_{\mathrm{SOA}}}{C_{\mathrm{SOG}}}=K_{p} M_{\mathrm{absorb}}=\frac{M_{\mathrm{absorb}}}{C^{*}}
$$

where $C_{\mathrm{SOA}}$ and $C_{\mathrm{SOG}}$ are the mass concentration $\left(\mu \mathrm{g} \mathrm{m}^{-3}\right)$ of certain species in the aerosol and gas phases, respectively. $M_{\text {absorb }}$ is the mass concentration $\left(\mu \mathrm{g} \mathrm{m}^{-3}\right)$ of the total absorbing particle phase and refers only to the particulate matter participating in absorptive partitioning.

If the oxidation of a hydrocarbon (HC) leads to $n$ semivolatile products, Odum et al. (1996) showed that the SOA yield $Y$, defined as the mass of SOA produced $\left(\Delta M_{\mathrm{OA}}\right)$ per unit mass of hydrocarbon oxidized $\left(\Delta M_{\mathrm{HC}}\right)$, can be derived from Eq. (1) and expressed as:

$Y=\frac{\Delta M_{\mathrm{OA}}}{\Delta M_{\mathrm{HC}}}=\sum_{k=1}^{n} \frac{\alpha_{k} K_{p, k} M_{\mathrm{absorb}}}{1+K_{p, k} M_{\mathrm{absorb}}}=\sum_{k=1}^{n} \frac{\alpha_{k}}{1+C_{k}^{*} / M_{\mathrm{absorb}}}$

where $\alpha_{k}$ is the mass-based stoichiometric yield of product $k$, and $n$ is total number of products.

Because of the large number of products formed in a given $\mathrm{HC}$ oxidation reaction and the difficulty in measuring individual semi-volatile compounds, two surrogate products (i.e., $n=2$ ) have been widely used to express the volatility distribution of the oxidation products (Odum et al., 1996) and are considered as the standard means of representing laboratory SOA yield data in many experimental studies (Seinfeld and Pankow, 2003). The two-product (2p) model of SOA formation (i.e., $n=2$ in Eq. 2), when applied to describe SOA formation from mixes of $N$ parent HCs, is referred as the $N \times 2 \mathrm{p}$ model (Pankow and Barsanti, 2009). The $N \times 2$ p SOA formation model has been employed in a number of regional and global models such as CMAQ (Carlton et al., 2010), CMAQMADRID (Zhang et al., 2004), GEOS-Chem (Chung and Seinfeld, 2002; Liao et al., 2007); GISS GCM II-prime (Chung and Seinfeld, 2002), and TM-3 with CBM-4 (Tsigaridis and Kanakidou, 2003).

It should be noted that the above described $N \times 2 \mathrm{p}$ SOA formation model has been derived based on laboratory measurements which generally last for several hours. As a result, the $N \times 2 \mathrm{p}$ SOA formation model does not take into account the SOG aging process which has been observed in the atmosphere and in the laboratory for the time beyond several hours of reactions (Donahue et al., 2006; Rudich et al., 2007; Kroll and Seinfeld, 2008; Hallquist et al., 2009; Jimenez et al., 2009). It has been found in these recent investigations that OA and OA precursor gases become increasingly oxidized, less volatile, and more hygroscopic as a result of continuous aging in the atmosphere (e.g., Jimenez et al., 2009). Kroll and Seinfeld (2008) pointed out that, in order to gain a quantitative and predictive understanding of SOA formation, the volatility changes arising from the aging process must be parameterized and included in models.

The traditional equilibrium partitioning-based $N \times 2 \mathrm{p}$ model does not model the kinetic growth of particles by condensation, which is a kinetic rather than an equilibrium process. The equilibrium approach assumes that the secondary organics in the particle phase and gas phase are always in instantaneous equilibrium which is a good approximation for organics with relatively high saturation vapor pressure. Based on equilibrium, the gas concentrations of low volatile species (such as $\mathrm{H}_{2} \mathrm{SO}_{4}$ and well aged SOGs with very low $C^{*}$ ) are very low. In the real atmosphere, it takes time for low volatile condensable vapors produced in-situ to get into particles (i.e., diffusion limited) and thus substantial concentrations of low volatile condensable species can build up in the atmosphere. As mentioned earlier, field measurements indicate that the growth rates of nucleated particles are commonly a factor of $\sim 2-20$ higher than can be explained by the $\mathrm{H}_{2} \mathrm{SO}_{4}$ vapor condensation alone, likely a result of SOA condensation (e.g., Kuang et al., 2010). Since the particle growth rates are essential to properly account for the contribution of nucleated particles to $\mathrm{CCN}$ and thus accurately predict the $\mathrm{CCN}$ concentrations, it is critical to understand the spatial-temporal variations of the concentrations of condensable SOGs and properly represent their contribution to secondary particle growth in the aerosol models. In addition, to explicitly resolve the growth of nucleated particles through the condensation (not partitioning) of aged SOGs is important in the sense that the condensation of low-volatile SOGs can enable additional more volatile organics to be uptaken through partitioning which further grow the secondary particles (Pankow and Barsanti, 2009).

In addition to the widely used empirical $N \times 2 \mathrm{p}$ model, a number of more sophisticate SOA formation models have also been developed in the past years. The Caltech Atmospheric Chemistry Mechanism and the Model to Predict 
the Multiphase Partitioning of Organics (CACM-MPMPO) considers more detailed information of semi-volatile organic compounds, and simultaneously treats the absorption of SOA into existing aerosol organic mass and dissolution of SOA into aerosol-phase water (Pun et al., 2002; Griffin et al., 2002, 2003). The semi-implicit CACM-MPMPO has been incorporated into the Community Multiscale Air Quality (CMAQ) model (Chen et al., 2006). Explicit models with detailed gas-phase oxidation schemes (thousands of reactions), based on Master Chemical Mechanism (Jenkin et al., 2004; Johnson et al., 2004, 2006) or NCAR Self-Generating Mechanism (Aumont et al., 2005; Camredon et al., 2007) have also been developed to predict SOA mass and speciation on the basis of first principles. These semi-implicit and fully explicit schemes can take into account multiple generations of oxidation and the volatility changes associated with oxidation aging. By separating organic aerosol and vapor mass into multiple logarithmically spaced saturation concentration bins, Donahue et al. (2006) developed a volatility basis set (VBS) approach to account for the wide range of organic compounds in the atmosphere and the ongoing oxidation of semi-volatile organics in both the gas and particle phases. In terms of the level of the complexity, the VBS approach lies between the computationally simple empirical $N \times 2$ p model and the detailed explicit models. More recently, Pankow and Barsanti (2009) proposed to use a carbon number (nC) vs. polarity grid (with concentration bins) for tracking the various OA-relevant compounds and their time dependent concentrations. The carbon number-polarity grid is aimed to enhance the complexity of the $N \times 2 \mathrm{p}$ approach by adding more products and to reduce the complexity of molecular kinetic models by using a set of chemical characteristics to lump products.

SOA formation models of different complexity have their own advantages and disadvantages. For 3-D application, one needs to balance the computational cost and the level of complexity. The current version of GEOS-Chem, which is a global 3-D chemical transport model developed and used by many research groups around the world to address a wide range of atmospheric composition problems, employs the simple but computationally efficient $N \times 2$ p model to simulate SOA formation (Chung and Seinfeld, 2002; Liao et al., 2007; Henze et al., 2008; Pye and Seinfeld, 2010). The main objectives of the present study are: (1) to extend the $N \times 2 p$ SOA formation model in GEOS-Chem to account for successive oxidation aging of SOGs and to represent the kinetic condensation of low-volatile SOGs on atmospheric particles (referred to as " $N \times 2 \mathrm{p}+\mathrm{A} / \mathrm{C}$ " model), without adding substantially to the computational burden of the model; (2) to investigate the impacts of the new scheme on simulated particle properties and global scale implications.

\section{SOA formation model considering successive oxidation aging and kinetic condensation $(N \times \mathbf{2 p}+\mathbf{A} / \mathbf{C})$}

In GEOS-Chem v8-2-3 on which this study is based, reactive biogenic volatile organic compounds (VOCs) are grouped into six categories $\left(\mathrm{VOC}_{i}, i=1-6\right)$, with $\mathrm{VOC}_{1}=\alpha$-pinene $+\beta$-pinene + sabinene + careen + terpenoid ketones; $\mathrm{VOC}_{2}=$ limonene; $\mathrm{VOC}_{3}=\alpha$-terpinene $+\gamma$-terpinene + terpinolene; $\mathrm{VOC}_{4}=$ myrcene + terpenoid alcohols + ocimene; $\mathrm{VOC}_{5}=$ sesquiterpenes; and $\mathrm{VOC}_{6}=$ isoprene. Grouping is based on rate constants and aerosol yield parameters determined from laboratory chamber studies (Griffin et al., 1999; Seinfeld and Pankow, 2003; Henze and Seinfeld, 2006), and schemes used to represent SOA formation from the oxidation of these VOCs have been described in Chung and Seinfeld (2002) and Liao et al. (2007). For each of the first four VOC categories $\left(\mathrm{VOC}_{1-4}\right)$, there are three oxidation products, two for combined $\mathrm{O}_{3}$ and $\mathrm{OH}$ oxidation and one for $\mathrm{NO}_{3}$ oxidation. There are only two products for sesquiterpenes (i.e., $\mathrm{VOC}_{5}$ : one for combined $\mathrm{O}_{3}$ and $\mathrm{OH}$ oxidation and one for $\mathrm{NO}_{3}$ oxidation) and for isoprene (i.e., $\mathrm{VOC}_{6}$ : two for combined $\mathrm{O}_{3}$ and $\mathrm{OH}$ oxidation and no $\mathrm{NO}_{3}$ oxidation). In brief, the oxidation reactions of $\mathrm{VOC}_{i}$ with $\mathrm{O}_{3}+\mathrm{OH}$ $\left(\mathrm{OX}_{1}\right)$ and $\mathrm{NO}_{3}\left(\mathrm{OX}_{2}\right)$ produce 16 groups of SOGs which then lead to the formation of 16 groups of SOAs through equilibrium partitioning (Chung and Seinfeld, 2002; Liao et al., 2007),

$\mathrm{VOC}_{i}+\mathrm{OX}_{1} \rightarrow \alpha_{i, 1,1} \mathrm{SOG}_{i, 1,1}+\alpha_{i, 1,2} \mathrm{SOG}_{i, 1,2} \longleftrightarrow$ SOAs

$\mathrm{VOC}_{i}+\mathrm{OX}_{2} \rightarrow \alpha_{i, 2,3} \mathrm{SOG}_{i, 2,3} \leftarrow \rightarrow$ SOAs

where $\alpha_{i, j, k}(i=1-6 ; j=1-2 ; k=1-3)$ are the mass-based Stoichiometric yields. $i, j, k$ are the indices for VOCs, oxidants, and oxidation products, respectively. The $\alpha_{i, j, k}$ values along with the equilibrium partition coefficients $K_{i, j, k}$ at reference temperatures $\left(T_{\text {ref }}\right)$ for each $\mathrm{SOG}_{i, j, k}$ can be found in Griffin et al. (1999) and Kroll et al. (2006).

The fractions of total secondary organic products $(\mathrm{SOG}+\mathrm{SOA})$ in gaseous and particulate phase depend on the products' effective saturation concentrations $C^{*}$ (in $\mu \mathrm{g} / \mathrm{m}^{3}$ ) which is the inverse of $K_{i, j, k}$ (Donahue et al., 2006). The temperature dependence of $C^{*}$ can be determined by the Clausius-Clapeyron equation:

$C_{T}^{*}=C_{T_{\text {ref }}}^{*} \frac{T_{\text {ref }}}{T} \exp \left[\frac{\Delta H}{R}\left(\frac{1}{T_{\text {ref }}}-\frac{1}{T}\right)\right]$

where $\Delta H$ (in kJ mol${ }^{-1}$ ) is the enthalpy of vaporization and $R$ is the gas constant.

$\Delta H$ is an important parameter controlling the SOA formation because of large variations in tropospheric temperatures and hence $C^{*}$ of various SOGs. $\Delta H$ values for various organic compounds derived from different laboratory studies differ significantly, ranging from $\sim 10 \mathrm{~kJ} \mathrm{~mol}^{-1}$ to 
$\sim 180 \mathrm{~kJ} \mathrm{~mol}^{-1}$ (e.g., Bilde and Pandis, 2001; Chattopadhyay and Ziemann, 2005; Offenberg et al., 2006; Donahue et al., 2006; Pathak et al., 2007; Stanier et al., 2007; Svendby et al., 2008; Saathoff et al., 2009; Epstein et al., 2010). It has been well recognized that a discrepancy exists in the derived $\Delta H$ values for complex SOA systems (or lumped organics) and for single component systems (or individual surrogates) (e.g., Offenberg et al., 2006; Donahue et al., 2006; Saathoff et al., et al., 2009; Epstein et al., 2010). Offenberg et al. (2006) showed that $\Delta H$ values for single component organic aerosols generated by nebulization of aqueous solutions are in the range of 13$140 \mathrm{~kJ} \mathrm{~mol}^{-1}$ but those for photochemically produced SOA (lumped organics) are in the range of $11-44 \mathrm{~kJ} \mathrm{~mol}^{-1}$, depending on types of organics in the solution $(13,27,65$, 89,112 , and $140 \mathrm{~kJ} \mathrm{~mol}^{-1}$ for glyoxal, methylglyoxal, glutaric acid, malonic acid, succinic acid, and pimelic acid, respectively) or reactant hydrocarbons (33-44 $\mathrm{kJ} \mathrm{mol}^{-1}$ for $\alpha$ pinene and $14-18 \mathrm{~kJ} \mathrm{~mol}^{-1}$ for toluene/propene). Based on their analysis of experimental data from a collection of different smog chambers, Pathak et al. (2007) derived an effective $\Delta H$ of $\sim 30 \mathrm{~kJ} \mathrm{~mol}^{-1}$ for $\alpha$-pinene SOA. Svendby et al. (2008) examined a large number of smog chamber experiments for monoterpenes ( $\alpha$-pinene and $\beta$-pinene) and aromatics (toluene and m-xylene) and found that $\Delta H$ values for relatively volatile SOAs from monoterpene oxidation are in the range of $40-60 \mathrm{~kJ} \mathrm{~mol}^{-1}$ but can reach $100 \mathrm{~kJ} \mathrm{~mol}^{-1}$ for low volatile oxidation products. In the work of Svendby et al. (2008), $\Delta H$ was estimated to be 31 and $48 \mathrm{~kJ} \mathrm{~mol}^{-1}$ for toluene and m-xylene, respectively. A recent chamber study reported in Saathoff et al. (2009) provides a substantial amount of new data on the temperature dependence of aerosol yields from the ozonolysis of $\alpha$-pinene and limonene under a wide temperature range (243-313 K). Using a twoproduct modeling framework, Saathoff et al. (2009) derived $\Delta H$ values for two more and less volatile product proxies of $\alpha$-pinene: $(24 \pm 9) \mathrm{kJ} \mathrm{mol}^{-1}$ and $(59 \pm 8) \mathrm{kJ} \mathrm{mol}^{-1}$, and limonene: $(25 \pm 12) \mathrm{kJ} \mathrm{mol}^{-1}$ and $(55 \pm 14) \mathrm{kJ} \mathrm{mol}^{-1}$.

Both Svendby et al. (2008) and Saathoff et al. (2009) showed that less volatile components of lumped SOA products have a notably high enthalpy of vaporization. Large and oxidized organic compounds generally have low $C^{*}$ and high $\Delta H$ values because of their chemical structure and bonding, and $\Delta H$ appears to correlate well with $C^{*}$ (Epstein et al., 2010). Based on published experimental vapor pressure data for over 800 organic compounds, Epstein et al. (2010) developed a semi-empirical correlation between $C^{*}$ at $300 \mathrm{~K}$ $\left(C_{300}^{*}\right.$, in $\left.\mu \mathrm{g} \mathrm{m}^{-3}\right)$ and $\Delta H\left(\right.$ in $\left.\mathrm{kJ} \mathrm{mol}^{-1}\right)$ :

$\Delta H=129-11 \log _{10} C_{300}^{*}$

Equation (9) gives a $\Delta H$ value of $129 \mathrm{~kJ} \mathrm{~mol}^{-1}$ for $C_{300}^{*}=1 \mu \mathrm{g} \mathrm{m}^{-3}$, with a slope of $-11 \mathrm{~kJ} \mathrm{~mol}^{-1}$ per decade and is an update of a similar parameterization given in Donahue et al. (2006) which assumed a $\Delta H$ of $100 \mathrm{~kJ} \mathrm{~mol}^{-1}$ for $C_{300}^{*}=1 \mu \mathrm{g} \mathrm{m}^{-3}$, with a slope of $-5.8 \mathrm{~kJ} \mathrm{~mol}^{-1}$ per decade of $C_{300}^{*}$ change. Equation (6) is derived for simple component systems and may not be appropriate for lumped organics in the $2 \mathrm{p}$ SOA formation model which generally have a lower effective $\Delta H$ (Donahue et al., 2006; Epstein et al., 2010; Pye and Seinfeld, 2010).

Poorly defined $\Delta H$ is a significant source of uncertainty in global modeling of SOA formation (Tsigaridis and Kanakidou, 2003). $\Delta H$ of $156 \mathrm{~kJ} \mathrm{~mol}^{-1}$ has been assumed in CMAQ version 4.3 (v4.3) through $\mathrm{v} 4.6$ but has recently been reduced to $40 \mathrm{~kJ} \mathrm{~mol}^{-1}$ for all biogenic SOA species in CMAQv4.7 (Carlton et al., 2010). $\Delta H$ is assumed to be $42 \mathrm{~kJ} \mathrm{~mol}^{-1}$ for all organic species in GEOS-Chem (Chung and Seinfeld, 2002; Henze and Seinfeld, 2006; Pye and Seinfeld, 2010). In these modeling studies, $\Delta H$ was assumed to be same for all organic compounds. In order to take into account the dependence of $\Delta H$ on $C^{*}$ which has been observed for both simple component systems (Epstein et al., 2010) and lumped organics in the $2 \mathrm{p}$ SOA formation model (Svendby et al. 2008; Saathoff et al. 2009), $\Delta H$ is parameterized as the following:

$$
\Delta H=\Delta H_{r e f}-A\left(\log _{10} C^{*}-\log _{10} C_{\text {ref }}^{*}\right)
$$

where $\Delta H_{\text {ref }}$ is the reference enthalpy of evaporation at reference $C^{*}$ and $A=d(\Delta H) / d \log _{10} C^{*}$ is the slope. In the present study, $\Delta H_{\text {ref }}$ is assumed to be $40 \mathrm{~kJ} \mathrm{~mol}^{-1}$ at $C_{\text {ref }}^{*}=100 \mu \mathrm{g} \mathrm{m}^{-3}$ at data reference temperature $(310 \mathrm{~K}$ for $\mathrm{VOC}_{1-5}$ and $295 \mathrm{~K}$ for $\mathrm{VOC}_{6}$ ). Based on Epstein et al. (2010), $A$ is chosen to be $-11 \mathrm{~kJ} \mathrm{~mol}^{-1}$ per decade. Table 1 gives $\alpha_{i, j, k}$ value for each $\operatorname{SOG}_{i, j, k}$ and their $C^{*}$ and $\Delta H$ values at $T=290 \mathrm{~K}$. Compared to the uncertainty in $\Delta H$, the effect of temperature on $\Delta H$ is small (Epstein et al., 2010) and is not considered here. Based on the parameterization given in Eq. (7), $\Delta H$ values range from $\sim 35-42 \mathrm{~kJ} \mathrm{~mol}^{-1}$ for MV-SOGs to $\sim 47-64 \mathrm{~kJ} \mathrm{~mol}^{-1}$ for SV-SOGs, consistent with notably higher $\Delta H$ values for less volatile components of lumped SOA products shown in chamber data (Svendby et al., 2008; Saathoff et al., 2009).

It is clear from Table 1 that $C^{*}$ differs significantly for different SOGs. According to their $C^{*}$, we group SOGs into two classes: semi-volatile SOG (SV-SOG) and mediumvolatile SOG (MV-SOG). SV-SOG includes the first oxidation product of $\mathrm{VOC}_{i}$ by $\mathrm{O}_{3}+\mathrm{OH}$, while MV-SOG includes the second oxidation product of $\mathrm{VOC}_{i}$ by $\mathrm{O}_{3}+\mathrm{OH}$ and the oxidation product of $\mathrm{VOC}_{i}$ by $\mathrm{NO}_{3}$. As discussed in the Introduction, it is important to extend the $N \times 2 \mathrm{p} \mathrm{SOA}$ formation model so that it can take into account the SOG aging process which has been observed in more recent atmospheric and laboratory measurements (e.g., Donahue et al., 2006; Jimenez et al., 2009). Additionally, the saturation vapor pressures of SV-SOG and MV-SOG are too high to directly condense on freshly nucleated sulfate particles and it becomes necessary to predict the concentration of condensable SOGs so that the kinetic condensation process can be considered. 
Table 1. Mass-based Stoichiometric yield $\left(\alpha_{i, j, k}\right)$ for semi-volatile products $(k=1-3)$ from the oxidation of major types of reactive biogenic volatile organic compounds $\left(\mathrm{VOC}_{i}, i=1-6\right)$ by different oxidants $(j=1,2)$, and the effective saturation concentrations $\left(C^{*}\right.$ in $\mu \mathrm{g} / \mathrm{m}^{3}$, inverse of equilibrium partition coefficient $\left.K_{i, j, k}\right)$ and the enthalpy of vaporization $\left(\Delta H\right.$, in kJ mol${ }^{-1}$ ) of these products at $T=290 \mathrm{~K} . i, j, k$ are the indices for VOCs, oxidants, and oxidation products, respectively. $\alpha_{i, j, k}$ value along with equilibrium partition coefficient $K_{i, j, k}$ at reference temperature $\left(T_{\text {ref }}\right)$ for each $\mathrm{SOG}_{i, j, k}$ can be found in Griffin et al. (1999a, b) and Kroll et al. (2006). $\Delta H$ is based on the parameterization given in Eq. (7).

\begin{tabular}{|c|c|c|c|c|c|c|c|c|c|}
\hline \multirow[b]{4}{*}{$\mathrm{VOC}_{i}$} & \multicolumn{6}{|c|}{$\mathrm{O}_{3}+\mathrm{OH}$ oxidation $\left(\mathrm{OX}_{1}\right)$} & \multirow{2}{*}{\multicolumn{3}{|c|}{$\frac{\mathrm{NO}_{3} \text { oxidation }\left(\mathrm{OX}_{2}\right)}{\text { Product type } 3}$}} \\
\hline & \multirow{2}{*}{\multicolumn{3}{|c|}{$\begin{array}{c}\text { Product type } 1 \\
\text { (SV-SOG) }\end{array}$}} & \multirow{2}{*}{\multicolumn{3}{|c|}{$\frac{\text { Product type } 2}{\text { (MV-SOG) }}$}} & & & \\
\hline & & & & & & & & MV-SOG) & \\
\hline & $\alpha_{i, 1,1}$ & $C_{i, 1,1} *$ & $\Delta H$ & $\alpha_{i, 1,2}$ & $C_{i, 1,2^{*}}$ & $\Delta H$ & $\alpha_{i, 2,3}$ & $C_{i, 2,3}{ }^{*}$ & $\Delta H$ \\
\hline$i=1$ & 0.067 & 1.38 & 54 & 0.354 & 95.58 & 36 & 1 & 21.13 & 42 \\
\hline$i=2$ & 0.239 & 5.36 & 48 & 0.363 & 75.01 & 37 & 1 & 21.13 & 42 \\
\hline$i=3$ & 0.069 & 1.98 & 52 & 0.201 & 119.77 & 35 & 1 & 21.13 & 42 \\
\hline$i=4$ & 0.067 & 1.10 & 55 & 0.135 & 45.85 & 39 & 1 & 21.13 & 42 \\
\hline$i=5$ & 1 & 6.58 & 47 & - & - & - & 1 & 21.13 & 42 \\
\hline$i=6$ & 0.029 & 0.40 & 64 & 0.232 & 89.53 & 39 & - & - & - \\
\hline
\end{tabular}

Figure 1 is a schematic illustration of particle formation and growth processes as well as the oxidation aging process considered in the present global size-resolved aerosol simulation. $\mathrm{H}_{2} \mathrm{SO}_{4}$ gas is well recognized to be involved in nucleation and also contributes to particle growth through condensation. $\mathrm{NH}_{3}$ and $\mathrm{HNO}_{3}$ can be uptaken by sulfate particles through thermodynamic equilibrium and contribute to aerosol growth and mass. Particles of various sizes are generally in equilibrium with $\mathrm{H}_{2} \mathrm{O}$ vapor and the hygroscopic growth factor depends on particle compositions. We extend the $N \times 2$ p model by adding a third component representing low-volatile secondary organic gases (LV-SOG) resulting from oxidation aging. The saturation vapor pressure of this LV-SOG is in the range of $\sim 0.01-3$ ppt and thus is low enough to condense on pre-existing particles. LV-SOG is important for particle growth because it not only directly contributes to the condensation growth but also acts as an absorbing mass and enables the particles to uptake SV-SOG and MV-SOG via absorptive partition. The saturation vapor pressures of SV-SOG and MV-SOG are typically in the range of $3 \mathrm{ppt}-3 \mathrm{ppb}$ and $0.3 \mathrm{ppb}-300 \mathrm{ppb}$, respectively.

The saturation vapor pressure of sulfuric acid gas over the flat surface of a $\mathrm{H}_{2} \mathrm{SO}_{4}-\mathrm{H}_{2} \mathrm{O}$ binary solution at $T=290 \mathrm{~K}$ and $\mathrm{RH}=50 \%$ is $\sim 0.001$ ppt. It is clear that $C_{\mathrm{H}_{2} \mathrm{SO}_{4}}^{*}<$ $C_{\mathrm{LV}-\mathrm{SOG}}^{*}<C_{\mathrm{SV}-\mathrm{SOG}}^{*}<C_{\mathrm{MV}-\mathrm{SOG}}^{*} \cdot \mathrm{H}_{2} \mathrm{SO}_{4}$ saturation vapor pressure is low enough to enable it to be involved in the nucleation process. LV-SOG generally has a substantial contribution to the growth of nucleated particles larger than $\sim 3 \mathrm{~nm}$, but their contribution to the growth of sub- $3 \mathrm{~nm}$ particles is likely limited as a result of the Kelvin effect (Yu and Turco, 2008; Wang et al., 2010). LV-SOA on secondary particles resulting from the condensation of LV-SOG serves as the absorbing mass $\left(M_{\text {absorb}}\right)$ and allow SV-SOGs and MV-SOGs to be uptaken through partitioning which further grow the secondary particles.

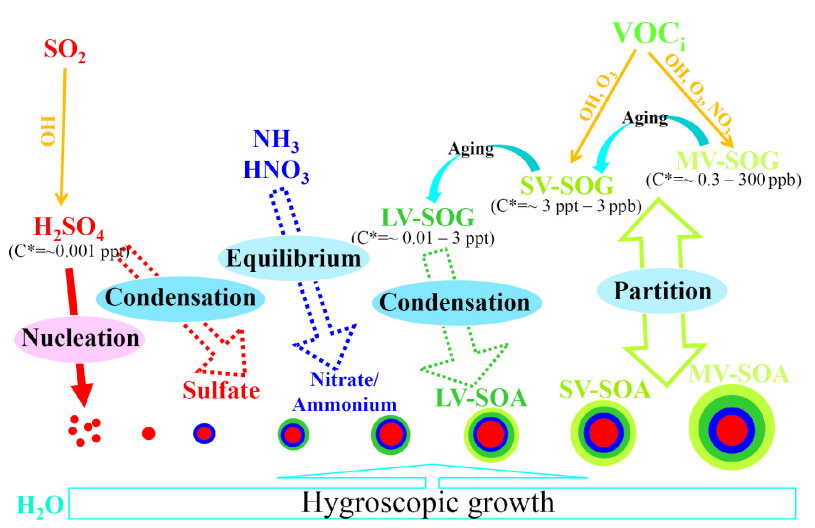

Fig. 1. Schematic illustration of particle formation and growth as well as oxidation aging processes in the atmosphere. See text for details.

The equations governing the changes of LV-, SV-, and MV-SOG concentrations $\left(C_{\mathrm{LV}-\mathrm{SOG}}, C_{\mathrm{SV}-\mathrm{SOG}}, C_{\mathrm{MV}-\mathrm{SOG}}\right)$ at a given grid box associated with chemical and microphysical processes are,

$$
\begin{aligned}
& d C_{\mathrm{MV}-\mathrm{SOG}} / d t=P_{\mathrm{VOC}}-K_{\mathrm{ag}}[\mathrm{OH}] \xi_{\mathrm{MV}->\mathrm{SV}} \\
& C_{\mathrm{MV}-\mathrm{SOG}}-L_{\mathrm{par}} \\
& d C_{\mathrm{SV}-\mathrm{SOG}} / d t=P_{\mathrm{VOC}}+K_{\mathrm{ag}}[\mathrm{OH}] \xi_{\mathrm{MV}->\mathrm{SV}} C_{\mathrm{MV}-\mathrm{SOG}} \\
& \quad-K_{\mathrm{ag}}[\mathrm{OH}] \xi_{\mathrm{SV}->\mathrm{LV}} C_{\mathrm{SV}-\mathrm{SOG}}-L_{\mathrm{par}} \\
& d C_{\mathrm{LV}-\mathrm{SOG}} / d t=K_{\mathrm{ag}}[\mathrm{OH}] \xi_{\mathrm{SV}->\mathrm{LV}} C_{\mathrm{SV}-\mathrm{SOG}}-L_{\mathrm{cond}}
\end{aligned}
$$

where $P_{\text {VOC }}$ is the VOC oxidation production term (Eqs. 34), $L_{\mathrm{par}}$ is the loss to aerosol via partitioning, and $L_{\text {cond }}$ is the loss to particle via condensation. $K_{\text {ag }}$ is the oxidation aging rate (Jimenez et al., 2009). In the present $N \times 2 \mathrm{p}+\mathrm{A} / \mathrm{C}$ SOA 
formation model, there are $6 \mathrm{SV}-\mathrm{SOG}$ and $10 \mathrm{MV}-\mathrm{SOG}$ considered (see Table 1). The transfer of mass from MVSOG to SV-SOG is based on the category of the parent $\mathrm{VOC}_{i}$ (i.e, from $\mathrm{MV}^{-\mathrm{SOG}_{i, 1,2}}$ and $\mathrm{MV}-\mathrm{SOG}_{i, 2,3}$ to $\mathrm{SV}_{-} \mathrm{SOG}_{i, 1,1}$, $i=1-6)$. All the oxidation products of SV-SOGs are lumped into one LV-SOG. Following Jimenez et al. (2009), we use a $K_{\text {ag }}$ value of $3 \times 10^{-11} \mathrm{~cm}^{3} \mathrm{~s}^{-1}$ in this study. $\xi_{\mathrm{MV}->\mathrm{SV}}$ is the fraction of each MV-SOG that can be oxidized to become the corresponding SV-SOG, and $\xi_{\mathrm{SV}->\mathrm{LV}}$ is the fraction of each SV-SOG that can be oxidized to become LV-SOG. It should be noted that transport and deposition of LV-, SV-, and MVSOGs, which are not included in Eqs. (8-10), are considered in the GEOS-Chem model. In the present study, Eqs. (8-10) are solved by operator splitting (partitioning, then oxidation, and then condensation) while the consumption of $\mathrm{OH}$ radicals by oxidation aging reactions is ignored. The loss rate to condensation is calculated via condensation growth equation (e.g., Yu, 2006) and to partitioning is based on the scheme described in Chung and Seinfeld (2002).

In the real atmosphere, all SOGs should react but only a fraction of SOGs in the category (MV-SOG, SV-SOG) has saturation vapor pressure lower enough to be moved to the next category (i.e, MV-SOG to SV-SOG, SV-SOG to LVSOG). The values of $\xi_{\mathrm{MV}->\mathrm{SV}}$ (or $\xi_{\mathrm{SV}->\mathrm{LV}}$ ) depend on the decrease of SOG saturation vapor pressure due to oxidation and the ratios of $C_{\mathrm{MV}}^{*}$ to $C_{\mathrm{SV}}^{*}$ (or $C_{\mathrm{SV}}^{*}$ to $C_{\mathrm{LV}}^{*}$ ) which differ for different SOGs and vary with temperature. To determine $\xi_{\mathrm{MV}->\mathrm{SV}}$ and $\xi_{\mathrm{SV}->\mathrm{LV}}$ is a challenging task. In the standard $N \times 2$ p SOA model and the VBS model, only one mean saturation vapor pressure is given for each SOG group/bin. In the real atmosphere, each SOG group/bin may contain hundreds of different organic species with saturation vapor pressures distributed around the mean value. To account for the spreading of saturation vapor pressures around the averaged values, we represent each SV-SOG or MV-SOG group with a normalized distribution in the $N \times 2 \mathrm{p}+\mathrm{A} / \mathrm{C}$ model,

$$
f_{\mathrm{SOG}}\left(C^{*}\right)=\frac{d F_{\mathrm{SOG}}\left(C^{*}\right)}{d \log C^{*}}=\frac{1}{\sqrt{2 \pi} \log \sigma_{g}} e^{\left[\frac{\left(\log C^{*}-\log \bar{C}_{\mathrm{SOG}}^{*}\right)^{2}}{2 \log \sigma_{g}}\right]}
$$

where $d F_{\mathrm{SOG}}\left(C^{*}\right)=f_{\mathrm{SOG}}\left(C^{*}\right) \times d \log C^{*}$ is the fraction of SOG having $C^{*}$ within $d \log C^{*} . \sigma_{g}$ is the geometric standard deviation and $\bar{C}_{\text {SOG }}^{*}$ is the median $C^{*}$. In this study, $\sigma_{g}$ is assumed to be 2 for baseline case and sensitivity studies for two additional $\sigma_{g}$ values (1.6 and 2.5) are presented. Lognormal distribution is a logical approach to approximate the spreading of $C^{*}$ around the mean value for each SOG group. The volatility change within each group is taken into account by assuming that the log-normal distribution of each SOG category is always maintained after a faction of the SOG in the left-tail (lowest $C^{*}$ ) of the log-normal distribution has been moved down to the next category. Therefore, the same material will have chance to be moved down after being oxidized multiple times. This approximation enables us to represent the $C^{*}$ changes associated with oxidation aging in the

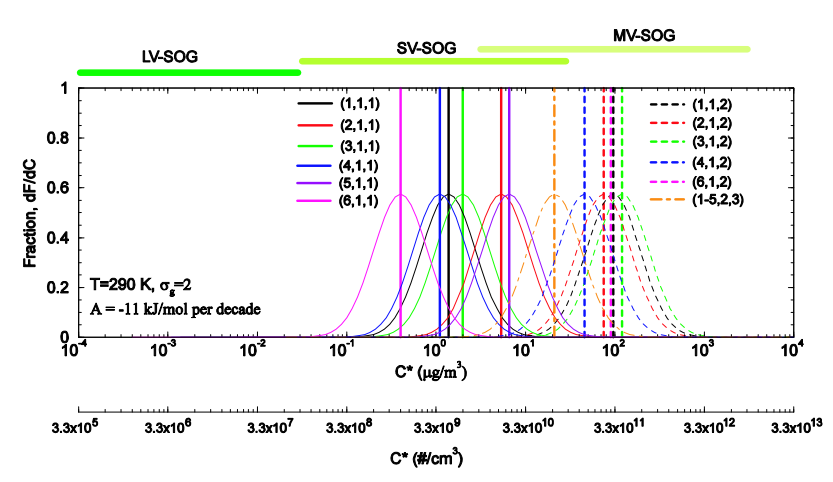

Fig. 2. Normalized distributions $\left(f_{\mathrm{SOG}}\left(C^{*}\right)\right.$, with geometric standard deviation $\sigma_{g}=2$ ) of $\mathrm{SOG}_{i, j, k}$ at $T=290 \mathrm{~K}$. The vertical lines are the median $C^{*}$. Second x-axis of $C^{*}$ in $\# / \mathrm{cm}^{3}$ is calculated from $C^{*}$ in $\mu \mathrm{g} / \mathrm{m}^{3}$ based on molecular weight of $181 \mathrm{~g} / \mathrm{mol}$. The numbers inside the parenthesis in the figure legend are $(i, j, k)$ of each product. See text for more information.

global model while keep the computational cost at a reasonable level. Further research is needed to reduce uncertainty associated with this approximation.

Figure 2 shows the normalized distributions $\left(f_{\mathrm{SOG}}\left(C^{*}\right)\right)$ of various SOGs at $T=290 \mathrm{~K}$. The saturation vapor pressure ranges of LV-, SV-, and MV-SOGs are also indicated in the figure. One benefit of normalized distribution is that it allows the integrated fraction of SOG below certain saturation vapor pressure values to change smoothly with temperature, which should be the case in the real atmosphere. It is clear from Fig. 2 that $C_{\mathrm{MV}}^{*} / C_{\mathrm{SV}}^{*}$ and $C_{\mathrm{SV}}^{*} / C_{\mathrm{LV}}^{*}$ vary substantially for different SOGs. To account for the effect of such variations on oxidation aging rates, we parameterize $\xi_{\mathrm{MV}->\mathrm{SV}}$ and $\xi_{\mathrm{SV}->\mathrm{LV}}$ values as,

$\xi_{\mathrm{SV}->\mathrm{LV}}=\int_{0}^{\varphi \overline{C_{\mathrm{LV}}^{\mathrm{upp}}}} f_{\mathrm{SV}-\mathrm{SOG}} d \log C$

$\xi_{\mathrm{MV}->\mathrm{SV}}=\int_{0}^{\varphi \overline{C_{\mathrm{SV}}^{*}}} f_{\mathrm{MV}-\mathrm{SOG}} d \log C$

where $f_{\text {SOG }}$ is the normalized distribution of each SOG group (Eq. 11, also see Fig. 2). $\overline{C_{\mathrm{LV}}^{\text {upp }}}$ is the upper limit of LVSOG saturation vapor pressure, estimated to be $0.03 \mu \mathrm{g} / \mathrm{m}^{3}$ in this study from the observed contribution of low volatile organics to the growth rates of nucleated particles (and hence the typical concentration of LV-SOG) and Kelvin effect. $\overline{C_{\mathrm{SV}}^{*}}$ is the geometric mean saturation vapor pressure of SV-SOG under a given temperature. $\phi$ is the ratio of the saturation vapor pressure of SOG to that of its one generation oxidation product. $\varphi \overline{C_{\mathrm{LV}}^{\mathrm{upp}}}$ and $\varphi \overline{C_{\mathrm{SV}}^{*}}$ are the cut-off saturation vapor pressures below which the SV-SOG and MV-SOG can be oxidized (in one generation) to become LV-SOG and SV-SOG, respectively. According to the structure activity relationships 
described by Pankow and Asher (2008), added -OH functionality decreases the $C^{*}$ of an organic backbone by a factor of $\sim 10^{2}$, while added $=\mathrm{O}$ functionality decreases $C^{*}$ by a factor of 10. Following the value suggested in Jimenez et al. (2009), we assume that each generation of oxidation by $\mathrm{OH}$ adds one oxygen atom and reduces $C^{*}$ by 1.5 decades (i.e., $\phi=10^{1.5}$ ).

The $N \times 2 \mathrm{p}+\mathrm{A} / \mathrm{C}$ approach presented in this manuscript can be considered as an alternative to the VBS approach (Donahue et al., 2006) to simulate the SOA formation in 3-D models. Both $N \times 2 \mathrm{p}+\mathrm{A} / \mathrm{C}$ and VBS approaches can cover a wide range of organic compounds and their successive oxidation in the atmosphere. One major difference between the two approaches is that the VBS employs logarithmically spaced $C^{*}$ "bins" while the $N \times 2 \mathrm{p}+\mathrm{A} / \mathrm{C}$ uses multiple lognormal $C^{*}$ distributions. In the VBS approach, the widely used $N \times 2 \mathrm{p}$ model is completely replaced with a selected number of $C^{*}$ "bins" and various smog chamber data of SOA formation have to be re-analyzed to obtain the mass yields of products in each $C^{*}$ bin. In the $N \times 2 \mathrm{p}+\mathrm{A} / \mathrm{C}$ approach, the $N \times 2 \mathrm{p}$ component (including all experimentally derived key yield parameters, equilibrium partitioning coefficients, etc.) is fully retained and is extended to account for the oxidation aging and kinetic condensation. To our knowledge, the kinetic condensation of low volatile SOGs is not considered in the present version of VBS model.

\section{Global SOA formation and particle growth modeling with GEOS-Chem + APM}

The model employed in this study is the GEOS-Chem model with an advanced particle microphysics (APM) model incorporated (Yu and Luo, 2009). The GEOS-Chem model is a global 3-D model of atmospheric composition driven by assimilated meteorological data from the NASA Goddard Earth Observing System 5 (GEOS-5), has been developed and used by many research groups, and contains a number of state-ofthe-art modules treating various chemical and physical processes (e.g., Bey et al., 2001; Martin et al., 2003; Park et al., 2004; Evans and Jacob, 2005; Liao et al., 2007) with up-to-date key emission inventories (e.g., Guenther et al., 2006; Bond et al., 2007; Zhang et al., 2009). A detailed description of the GEOS-Chem (including various emission sources, chemistry and aerosol schemes) can be found in the model webpage (http://acmg.seas.harvard.edu/geos). The APM model will be incorporated into the standard version of GEOS-Chem in the near future. The details of aerosol representation and processes in GEOS-Chem + APM can be found in Yu and Luo (2009).

In this work, we implement the $N \times 2 \mathrm{p}+\mathrm{A} / \mathrm{C}$ SOA formation scheme described in Sect. 2 in GEOS-Chem+APM and use the updated model to study the effect of oxidation aging and LV-SOG explicit condensation on simulated particle properties in the global scale. The co-condensation of $\mathrm{H}_{2} \mathrm{SO}_{4}$ and LV-SOG on size-resolved secondary particles (represented by 40 bins: 30 bins for dry diameter of $1.2 \mathrm{~nm}-120 \mathrm{~nm}$ and 10 bins for dry diameter of $0.12 \mu \mathrm{m}-12 \mu \mathrm{m}$ ) is explicitly simulated (Yu and Turco, 2008), along with the scavenging of these precursors by primary particles. To reduce the number of tracers in the model, we lump all LV-SOA on secondary particle (SP) of different sizes into one tracer (SP_LV) and redistribute SP_LV into different sizes according to SP surface area when needed. Similar to the amount of sulfate coated on various primary particles (Yu and Luo, 2009), we use four additional tracers (dust_LV, BC_LV, POC LV, and salt_LV) to track the amount of LV-SOA coated on various primary particles (i.e., dust, black carbon, primary organic carbon, and sea salt) as a result of condensation and coagulation. We assume that LV-SOG has similar deposition and scavenging parameters as $\mathrm{H}_{2} \mathrm{SO}_{4}$. The deposition and scavenging parameters for SP $\_V, B C \_L V, P O C \_L V$, and salt $L V$ follow those of sulfate in these different types of particles. The deposition and scavenging parameters for SV-SOGs and MV-SOGs follow the original GEOS-Chem scheme for these species (Chung and Seinfeld, 2002; Liao et al., 2007). The implementation of the $N \times 2 \mathrm{p}+\mathrm{A} / \mathrm{C}$ SOA formation scheme adds 6 additional tracers ( 5 for LV-SOA on different types of particles and 1 for LV-SOG), with a small increase in the computing cost $(<5 \%)$. The schemes within APM are designed with special emphasis on capturing the main properties of atmospheric particles important for their direct and indirect radiative forcing while keeping computational costs low.

The GEOS-Chem v8-01-03 used in Yu and Luo (2009) has been updated to v8-02-03 for the present simulation. All the annual mean results given below are based on simulations for year 2005 (2-month spin up time) with a horizontal resolution of $4^{\circ} \times 5^{\circ}$ and 47 vertical layers up to $0.01 \mathrm{hpa}$ (GEOS-5 meteorological fields). We also run the model at a horizontal resolution of $2^{\circ} \times 2.5^{\circ}$ from 1 March 2005- 31 May 2005 while the output for May 2005 was saved every 30 min for comparisons with size distribution measurements at Hyytiälä, Findland. New particle formation is calculated based on an ion-mediated nucleation mechanism (Yu, 2010) which is based on state-of-the-art thermodynamic and laboratory data (Yu, 2010) and has been validated against well constrained case studies of nucleation events observed in boreal forests (Yu and Turco, 2008). Previous global modeling studies indicate that the IMN mechanism appears to reasonably account for total number concentrations of particles larger than $\sim 4 \mathrm{~nm}$ and $\sim 10 \mathrm{~nm}$ observed in different parts of the troposphere (Yu and Luo, 2009, 2010; Yu et al., 2010).

Figure 3 shows the horizontal distributions of annual mean values of $\mathrm{H}_{2} \mathrm{SO}_{4}$ gas concentration ([ $\left.\left.\mathrm{H}_{2} \mathrm{SO}_{4}\right]\right)$, LV-SOG concentration [LV-SOG], and the ratio of [LV-SOG] to $\left[\mathrm{H}_{2} \mathrm{SO}_{4}\right]$ in the boundary layer (averaged within the first seven model layers above the Earth's surface: $0-1 \mathrm{~km}$ ). [LV-SOG] is a factor of $\sim 2-20$ higher than $\left[\mathrm{H}_{2} \mathrm{SO}_{4}\right]$ over many parts of the continents but is lower or close to $\left[\mathrm{H}_{2} \mathrm{SO}_{4}\right]$ in East Asia, 
middle and southern Europe, and the eastern United States where anthropogenic $\mathrm{SO}_{2}$ sources are strong. It should be noted that direct emissions or evaporation of low volatile anthropogenic VOCs and the aging of anthropogenic VOCs are not included in the present SOA formation model described in Sect. 2. There exists evidence that primary anthropogenic organic compounds can evaporate, age and contribute to SOA formation in source regions (Volkamer et al., 2006; Robinson et al., 2007; Henze et al., 2008; Pye and Seinfeld, 2010). Further research is needed to investigate how the processing and oxidation aging of anthropogenic VOCs may affect [LV-SOG] in their source regions. It is clear from Fig. 3 that the high [LV-SOG] is limited to continents and [LV-SOG] over oceans is generally much lower than $\left[\mathrm{H}_{2} \mathrm{SO}_{4}\right]$. This is a result of the short life of biogenic VOCs and lack of LV-SOG production over oceans. It is noteworthy that a number of recent studies indicate the oceanic sources of isoprene and alpha-pinene (Meskhidze and Nenes, 2006; Roelofs, 2008; Yassaa et al., 2008; Luo and Yu, 2010), which are not included in this study because of the large difference in the source strength estimated from "bottom-up" and "topdown" methods (Arnold et al., 2009; Gantt et al., 2009; Luo and $\mathrm{Yu}, 2010)$. Depending on the source strength of oceanic VOC emission, [LV-SOG] over oceans could increase substantially. Further research is needed to characterize the contributions of the aging of anthropogenic VOCs and oceanic VOC emissions to the LV-SOG concentration and the associated impact on particle properties.

As pointed out in Sect. 2, the saturation vapor pressure of LV-SOG $(\sim 0.01-3 \mathrm{ppt})$ is low enough for explicit condensation. In this study, we assume that LV-SOG has an average saturation vapor pressure of $0.15 \mathrm{ppt}$ (equivalent to $\sim 5 \times 10^{6} \mathrm{~cm}^{3}$ ) and the co-condensing of $\mathrm{H}_{2} \mathrm{SO}_{4}$ and $\mathrm{LV}$ SOG is explicitly resolved in the model. Figure 4 shows the simulated particle size distribution evolution based on the original $N \times 2 \mathrm{p}$ SOA formation model (i.e., no oxidation aging and explicit condensation of LV-SOG) and the extended $N \times 2 \mathrm{p}+\mathrm{A} / \mathrm{C}$ SOA formation model described in Sect. 2 at a boreal forest site (Hyytiälä, Finland) during May, 2005. For comparison, the observed size distribution evolution for the same location during the same period is also given (data from the CREATE Aerosol Database). The long-term continuous particle size distribution measurements in Hyytiälä by Kulmala and colleagues provide excellent data illustrating the formation and growth of atmospheric particles and have been analyzed in a number of previous publications (Laakso et al., 2004; Kulmala et al., 2004; Ehn et al., 2007; Laaksonen et al., 2008). The monthly mean size distributions (of those shown in Fig. 4) along with the size-dependent correlation coefficient $(r)$ and normalized mean bias (NMB) are given in Fig. 5, showing quantitatively the ability of the model in capturing the diurnal variation of particle size distributions during a period of one month and the impact of SOG oxidation aging/kinetic condensation.

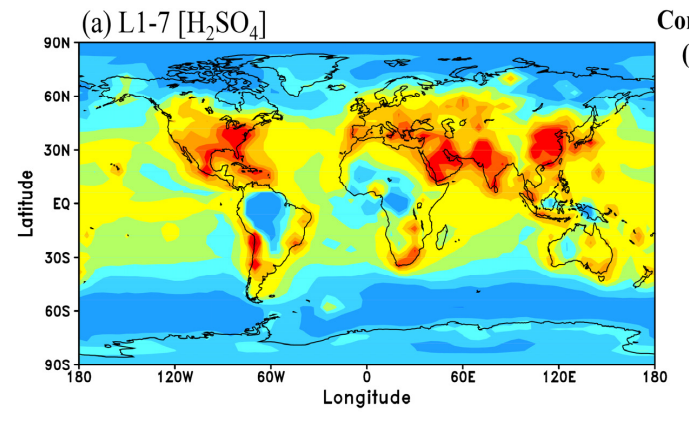

Concentration $\left(10^{6} \mathrm{~cm}^{-3}\right)$
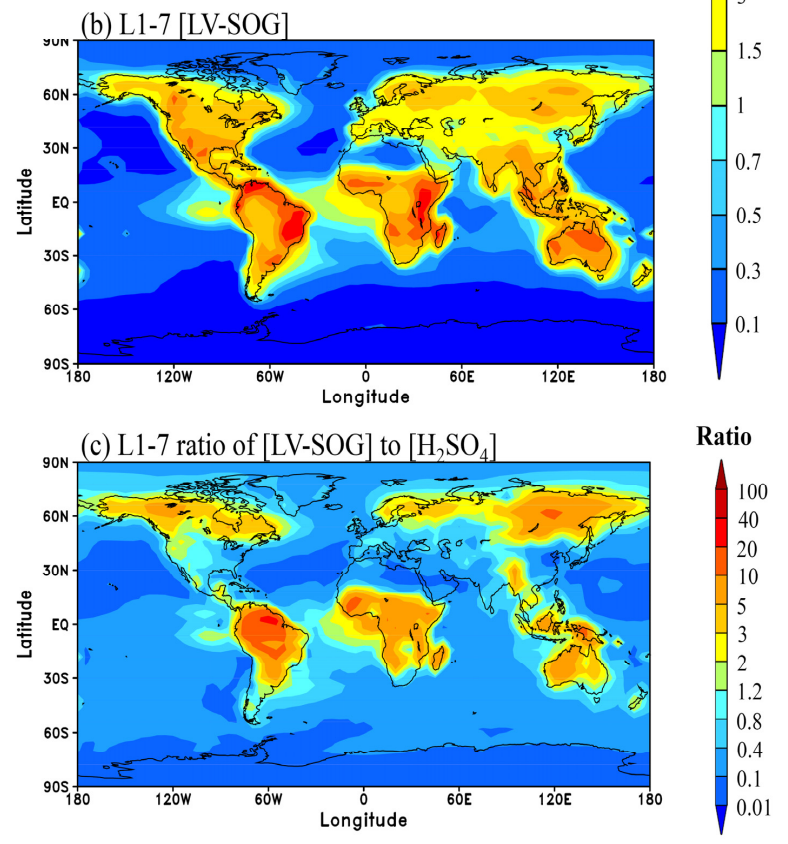

Fig. 3. Horizontal distributions (averaged over first seven model layers above Earth's surface: $0-1 \mathrm{~km}$ ) of annual mean values of (a) $\mathrm{H}_{2} \mathrm{SO}_{4}$ gas concentration $\left(\left[\mathrm{H}_{2} \mathrm{SO}_{4}\right]\right)$, (b) LV-SOG concentration [LV-SOG], and (c) ratio of [LV-SOG] to $\left[\mathrm{H}_{2} \mathrm{SO}_{4}\right]$. The simulation was carried out with GEOS-Chem + APM for year 2005 with a horizontal resolution of $4^{\circ} \times 5^{\circ}$ and 47 vertical layers up to 0.01 hpa (GEOS-5 meteorological fields).

It can be seen from Figs. 4 and 5 that the condensation of LV-SOG is important to bring the simulations closer to observations. Without $\mathrm{LV}-\mathrm{SOG}, \mathrm{H}_{2} \mathrm{SO}_{4}$ can only grow nucleated particles to around $\sim 10-30 \mathrm{~nm}$ within a day (Fig. 4a) and the model significantly under-predicts the number concentrations of particles larger than $\sim 20 \mathrm{~nm}$ while over-predicts those smaller than $\sim 20 \mathrm{~nm}$ (Fig. 5). In contrast, the participation of LV-SOG (plus the absorbing of SV-SOG and MV-SOG) drives the particles to $\sim 40-100 \mathrm{~nm}$ within the day (Fig. 4b). Our simulations indicate that $\mathrm{H}_{2} \mathrm{SO}_{4}$ account for $<\sim 20 \%$ of the growth rate of nucleated particles in the boreal forest, which is consistent with the observations (Kulmala et al., 2004). It is interesting to note that, when LV-SOG condensation is considered, nucleation events are shorter 


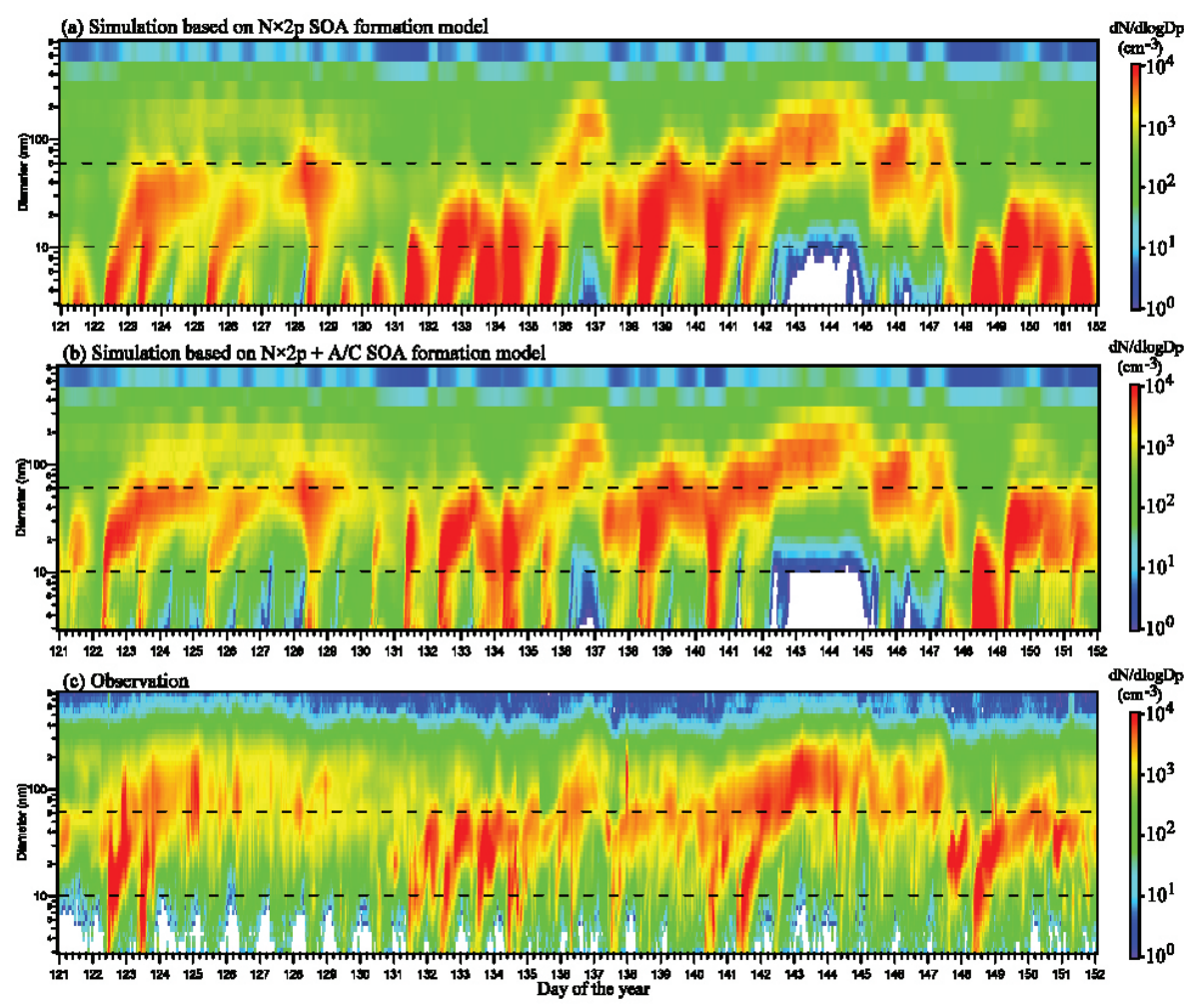

Fig. 4. A comparison of the simulated particle size distribution evolution based on (a) previous $N \times 2$ p SOA formation model (i.e., no oxidation aging and explicit condensation of LV-SOG) and (b) present $N \times 2 \mathrm{p}+\mathrm{A} / \mathrm{C}$ SOA formation model described in Sect. 2 , with (c) those observed in a boreal forest site (Hyytiälä, Finland) during May, 2005. The simulations are the results for the surface layer. The observation data are from the CREATE Aerosol Database at NILU and Markku Kulmala is the PI of the data. Further information of the size distribution measurements can be found in Laakso et al. (2004) and Ehn et al. (2007). The horizontal lines at $10 \mathrm{~nm}$ and $60 \mathrm{~nm}$ are added to guide the visual comparison of particle size distributions.

and generate fewer new particles. This is a result of increased particle surface area and reduced $\left[\mathrm{H}_{2} \mathrm{SO}_{4}\right]$ associated with enhanced growth rates. A comparison of Fig. $4 \mathrm{~b}$ with Fig. $4 \mathrm{c}$ shows that the overall agreement between simulated (with LV-SOG condensation) and observed size distributions is reasonable, indicating that the $N \times 2 \mathrm{p}+\mathrm{A} / \mathrm{C}$ SOA formation model may be able to capture some major processes of SOG oxidation aging and particle growth. The model reproduces a large fraction of strong nucleation events (days 122-123, 131-134, 140, 148) and weak or non-nucleation periods (days 124-130, 142-147, 150-152). The weak or non-nucleation periods appear to follow previous strong nucleation and growth events, suggesting some kind of particle number self-limiting process in the atmosphere.

There exist some differences in the simulated and observed nucleation and growth rates on some days (days 125, 128, $135,138)$. A comparison of the monthly mean size distributions (Fig. 5) indicates that the $N \times 2 \mathrm{p}+\mathrm{A} / \mathrm{C}$ scheme, while significantly improves the model performance, still underpredicts the number concentrations of particles in the size range of $\sim 40-400 \mathrm{~nm}$ by $10-40 \%$. The correlation coefficients $(r)$ given in Fig. $5 b$ show the ability of the model in capturing the concentration diurnal variations of particles of different sizes. $r$ values are high for accumulation mode particles because of relatively small diurnal variations of these particles. The $N \times 2 \mathrm{p}+\mathrm{A} / \mathrm{C}$ scheme substantially improves the model performance for particles of $\sim 6-60 \mathrm{~nm}$, with $r$ values above 0.3 for particles $<\sim 25 \mathrm{~nm}$ and between 0.2 and 0.3 for particles of $\sim 25-50 \mathrm{~nm}$. The relatively lower $r$ values for particles of $\sim 25-50 \mathrm{~nm}$ combined with the negative NMB values for particles of $\sim 25-300 \mathrm{~nm}$ and the positive NMB values for particles of $<\sim 25 \mathrm{~nm}$ suggest that the model may still under-predict the growth rate of nucleated particles in this boreal forest site. The differences in the predicted and observed evolution of particle size distributions may also be associated with the coarse model horizontal resolution $\left(2^{\circ} \times 2.5^{\circ}\right.$ grid box versus a fixed site $)$ and uncertainties in various processes (emissions, meteorology, chemistry, microphysics, cloud processing, etc.).

The detailed one to one comparison of particle size distribution evolution during a period of one month predicted by a global aerosol model with those observed at a given site is the first of its kind (to our knowledge) and the overall results are quite encouraging. It is clear from Figs. 4 and 5 that, 
(a) Monthly mean particle size distribution, Hyytiala, 200505

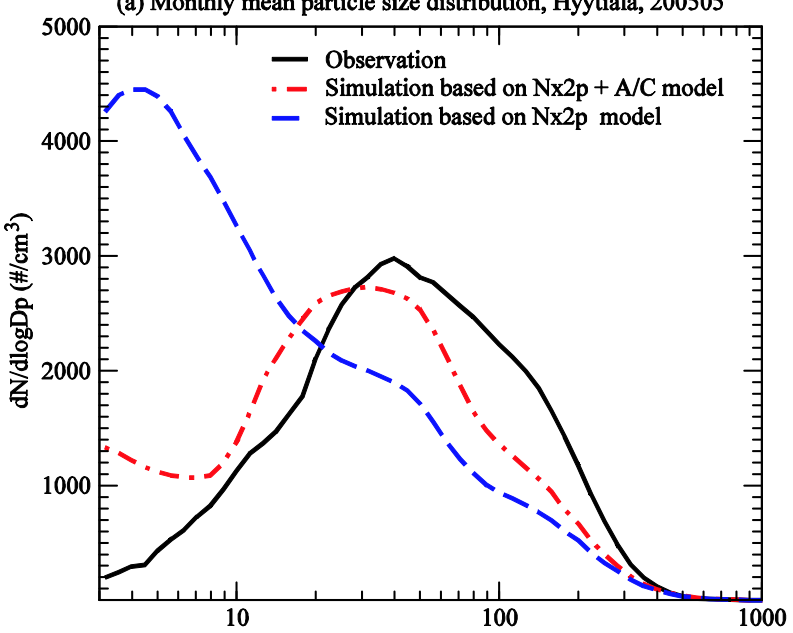

(b) Correlation Coefficient and NMB, Hyytiala, 200505

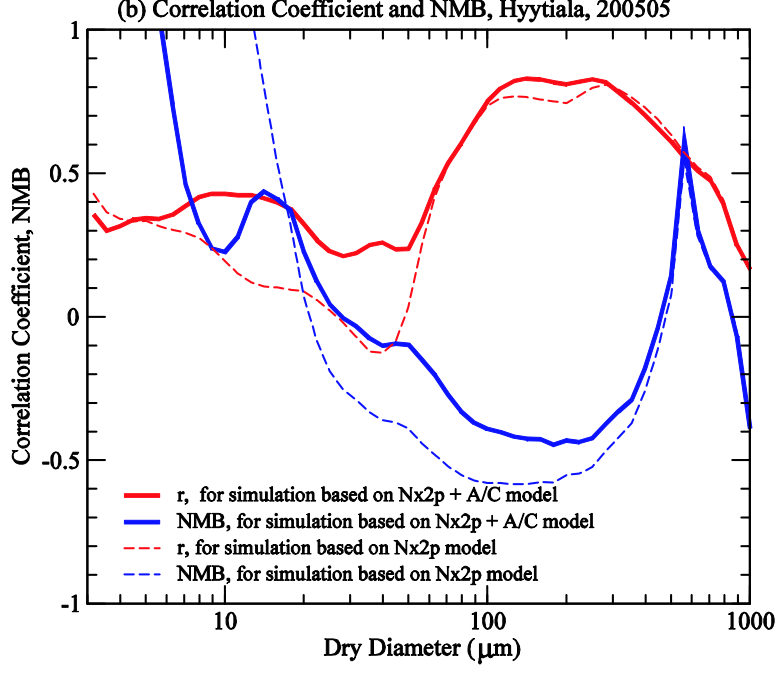

Fig. 5. (a) Same as Fig. 4 except for the monthly mean particle size distributions, (b) size-dependent correlation coefficient $(r)$ between simulated and observed number concentrations of particles of different sizes and the corresponding normalized mean bias (NMB).

consistent with various observations (Kulmala et al., 2004; Kuang et al., 2010), the consideration of LV-SOG condensation is critical and the extended SOA formation model may significantly advance the model's ability to simulate particle formation and growth in the troposphere.

The effect of the $N \times 2 \mathrm{p}+\mathrm{A} / \mathrm{C}$ scheme on simulated total SOA mass in the boundary layer is given in Fig. 6. For the simulation based on original $N \times 2 \mathrm{p}$ model (Fig. 6a), SOA can only form via absorptive partitioning with primary organic carbon (POC) and the annual mean SOA mass is generally $<0.3 \mu \mathrm{g} / \mathrm{m}^{3}$ in most parts of the boundary layer except in the eastern United States $\left(0.3-0.7 \mu \mathrm{g} / \mathrm{m}^{3}\right)$, eastern Asia $(0.3-$ $\left.2 \mu \mathrm{g} / \mathrm{m}^{3}\right)$, Australia (0.3-0.5), Southern Africa and Southern America (up to $5 \mu \mathrm{g} / \mathrm{m}^{3}$ ). With the $N \times 2 \mathrm{p}+\mathrm{A} / \mathrm{C}$ scheme that takes into account SOG oxidation aging and LV-SOG con- (a) L1-7 Total SOA based on $\mathrm{N} \times 2 \mathrm{p}$ model

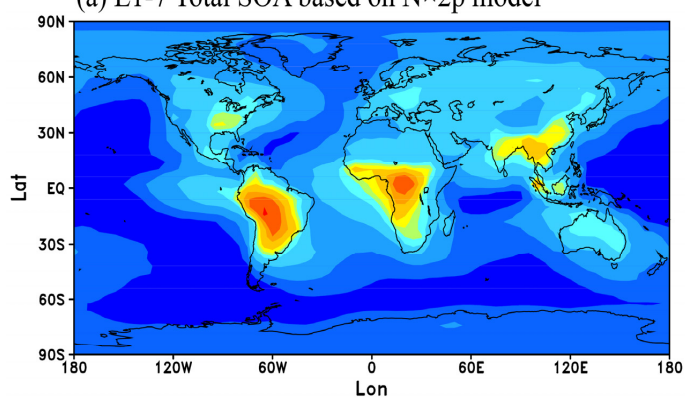

(b) L1-7 Total SOA based on $\mathrm{N} \times 2 \mathrm{p}+\mathrm{A} / \mathrm{C}$ model

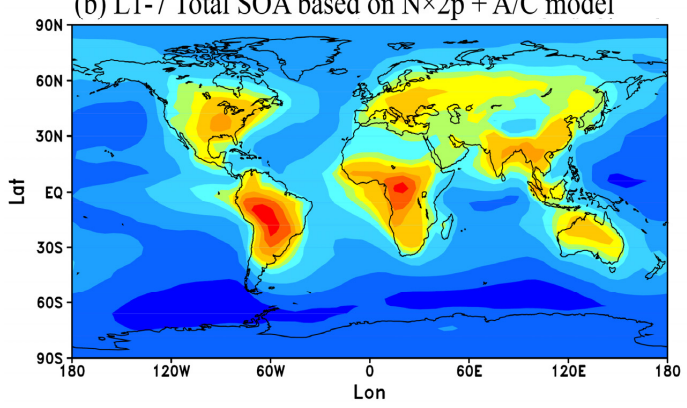

(c) L1-7 Total SOA change

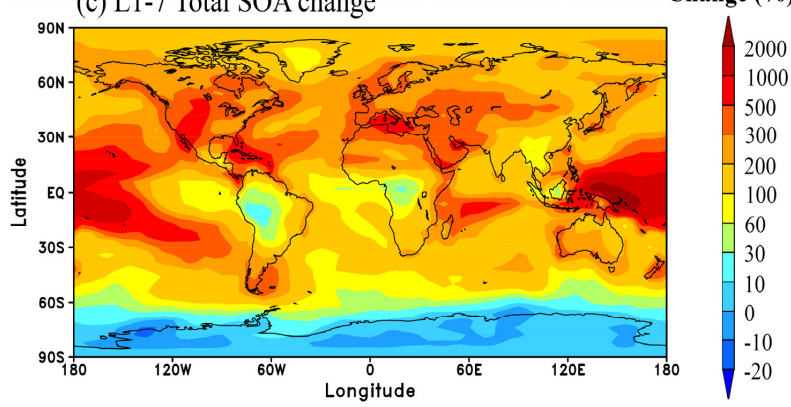

Total SOA

$\left(\mu \mathrm{g} \mathrm{m}^{-3}\right)$

10

7

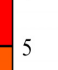

$-3$
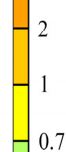

0.5

0.3

0.1

0.03

0.01
Fig. 6. Horizontal distributions of annual mean SOA mass concentrations in the boundary layer $(0-1 \mathrm{~km}$ above surface) simulated (a) with original $N \times 2 \mathrm{p}$ SOA formation model, (b) with the $N \times 2 \mathrm{p}+\mathrm{A} / \mathrm{C}$ SOA formation model described in this paper, and (c) percentage increase in SOA mass when SOG oxidation aging and LV-SOG condensation are considered.

densation, annual mean SOA mass in the boundary layer over the whole globe increases significantly, by a factor of $2-10$ in many parts of the boundary layer (Fig. 6c). Annual mean SOA mass reaches above $0.5 \mu \mathrm{g} / \mathrm{m}^{3}$ in most parts of the main continents, except in the high latitude Arctic and Antarctic regions $\left(<0.3 \mu \mathrm{g} / \mathrm{m}^{3}\right)$. The enhancement over the oceans is also significant although the absolute SOA mass is still quite low $\left(<\sim 0.1 \mu \mathrm{g} / \mathrm{m}^{3}\right)$.

Total SOA mass obtained at multiple surface locations in the Northern Hemisphere based on factor analysis of AMS data (FA-AMS), as presented in Jimenez et al. (2009), is largely in the range of $1-8 \mu \mathrm{g} / \mathrm{m}^{3}$. Most of the AMS measurements lasted a few weeks and many measurements were in the urban areas. Figure 7 shows a comparison of SOA mass concentrations observed at 25 sites around the globe (from 
Jimenez et al., 2009 and references therein) with simulated values in the lower boundary layer $(0-0.4 \mathrm{~km})$ corresponding to the seasons (spring, summer, fall, or winter, as specified in Jimenez et al., 2009) when the observations were made. We would like to emphasize that the simulated SOA mass concentrations given in Fig. 7 are seasonally averaged values for year 2005 based on the GEOS-Chem simulation with a horizontal resolution of $4^{\circ} \times 5^{\circ}$ while the observed values are averaged values during the measurement periods which lasted from 7 days to 127 days and were in different years for different sites (Jimenez et al., 2009). With these limitations kept in mind, one can conclude from Fig. 7 that $N \times 2$ p scheme significantly under-predicts the SOA mass $(\mathrm{NMB}=-0.74$ and -0.93 for rural and urban sites, respectively) and the $N \times 2 \mathrm{p}+\mathrm{A} / \mathrm{C}$ scheme substantially improves the agreement between predicted and observed SOA concentrations (NMB values change from -0.74 to -0.29 for rural sites and -0.93 to -0.82 for urban sites). The low horizontal resolution of the model simulations is likely to contribute to a large fraction of the deviations shown in Fig. 7, especially for those sites in the urban areas and elevated mountains. Some of the deviations can be attributed to the uncertainties in the SOA formation models, which can be seen from the vertical bars overlapped on filled symbols which present the simulated SOA mass concentrations when $\sigma_{g}$ value is changed from 2.0 (baseline value, filled symbols) to 1.6 (lower end) and to 2.5 (upper end). It should be noted that recent efforts to improve the SOA formation treatment in GEOS-Chem by adding aromatic species toluene, xylene, and, benzene (Henze et al., 2008) and emissions of semivolatile and intermediate volatility organic compounds (Pye and Seinfeld, 2010) are not incorporated in the present version of GEOS-Chem. These additional SOA formation pathways may account for some of the model under-predictions, especially in the source regions of these species. Further detailed comparisons of simulated SOA mass (at higher horizontal model resolution and during the specific periods of various observations, and with additional SOA formation pathways included) with AMS observations are needed to assess more confidently the ability of the model in capturing the SOA formation in various regions during different seasons.

Figure $8 \mathrm{a}$ shows the horizontal distributions of annual mean number concentrations of condensation nuclei larger than $10 \mathrm{~nm}(\mathrm{CN} 10)$ in the lower boundary layer $(0-0.4 \mathrm{~km})$ simulated with the new SOA formation model described in this paper. Overlaid on Fig. 8a for comparison (symbols) are the annual or multiple-year averaged $\mathrm{CN} 10$ values observed at 21 surface sites around the globe, with a more specific comparison of simulated $\mathrm{CN} 10$ with observed values given in Fig. 9. The sources of CN10 data include CREATE Aerosol Database at NILU (tarantula.nilu.no/projects/ccc/ create/index.htm), World Data Centre for Aerosols (wdca.jrc. ec.europa.eu), NOAA ESRL/GMD Aerosol Database (www. cmdl.noaa.gov/aero), Dal Maso et al. (2008), Ziemba et al. (2006), Laakso et al. (2008), Suni et al. (2008), Venzac et

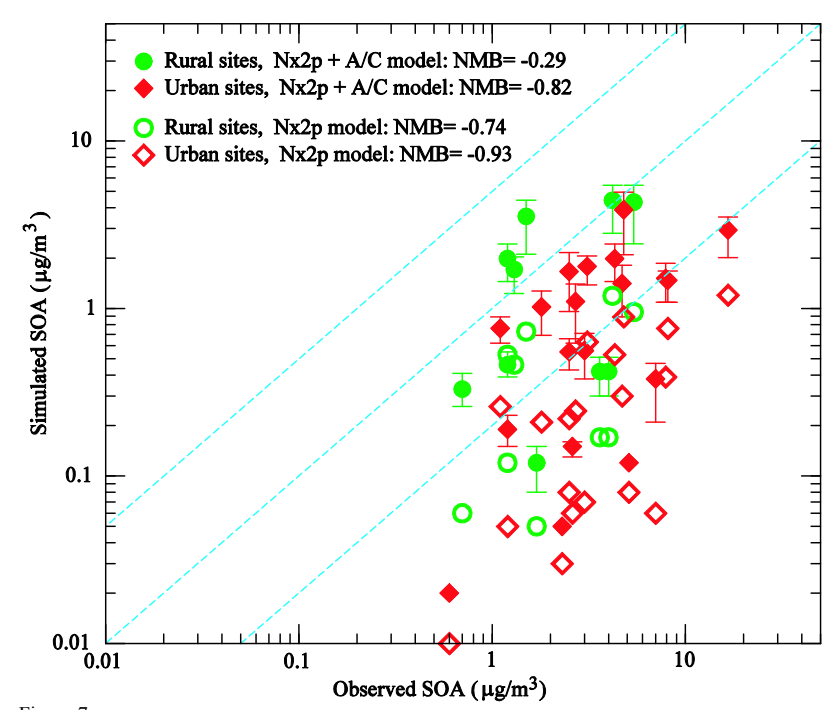

Fig. 7. Comparison of seasonally averaged SOA mass concentrations observed at 25 sites around the globe (Jimenez et al., 2009 and references therein) with those in the lower boundary layer $(0$ $0.4 \mathrm{~km}$ ) simulated with $N \times 2 \mathrm{p}$ (unfilled symbols) and $N \times 2 \mathrm{p}+\mathrm{A} / \mathrm{C}$ (filled symbols) SOA formation models. The vertical bars overlapped on filled symbols present the simulated SOA mass concentrations when the value of geometric standard deviation $\left(\sigma_{g}\right)$ in lognormal $C^{*}$ distribution (Eq. 11) is changed from 2.0 (baseline value, filled symbols) to 1.6 (lower end) and to 2.5 (upper end). The solid line shows a 1:1 ratio, and the dashed lines show ratios of 5:1 and $1: 5$.

al. (2008), Komppula et al. (2009), and Kivekäs et al. (2009). More details of these data can be found in Yu and Luo (2009). The impact of including LV-SOG condensation on the annual mean $\mathrm{CN} 10$ in the lower boundary layer $(0-0.4 \mathrm{~km})$ is presented in Fig. 8b. Enhanced growth rate associated with LVSOG condensation has two effects on CN10: (1) it increases the fraction of nucleated particles growing beyond $10 \mathrm{~nm}$; (2) it increases the surface area of particles (or condensation sink) which leads to a reduction in $\left[\mathrm{H}_{2} \mathrm{SO}_{4}\right]$ and nucleation rates. Our simulations indicate that, in most parts of the lower boundary layer, the second effect exceeds the first effect and the inclusion of LV-SOG condensation decreases CN10 by $3-30 \%$ (Fig. 8b). In terms of comparison with observed CN10 values, the inclusion of LV-SOG condensation slightly increases the normalized mean error (NME) (from 0.3 to 0.32 ) and absolute value of NMB (from -0.055 to -0.116 ). Both cases (with and without LV-SOG condensation) appear to capture the annual mean $\mathrm{CN} 10$ values within a factor of $\sim 2$. The results presented in Figs. 4 and 8 highlight the necessity to use aerosol measurements in addition to CN10 data (such as size distributions, etc.) to validate global aerosol models.

Figure 10 gives total $\mathrm{CCN}$ concentration at a water supersaturation ratio of $0.2 \%$ (CCN0.2) in the lower troposphere (lowest $2 \mathrm{~km}$, averaged within the lowest 14 model 


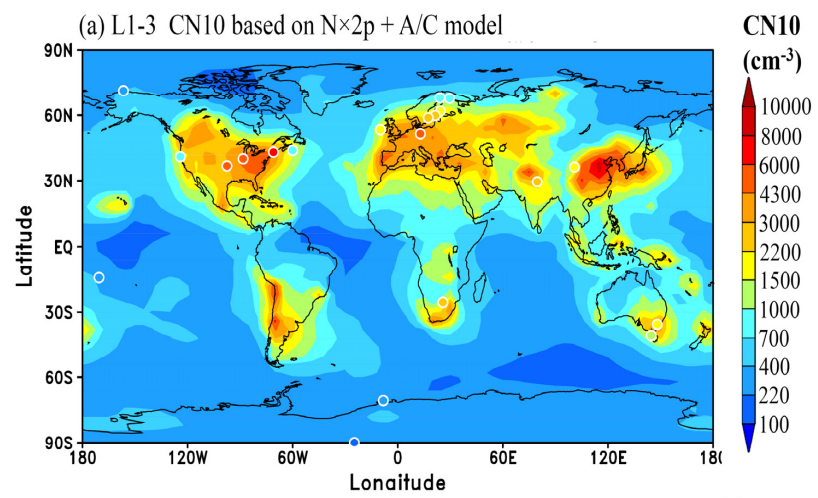

(b) L1-3 CN10 change compared to those based on $\mathrm{N} \times 2 \mathrm{p}$ model Change

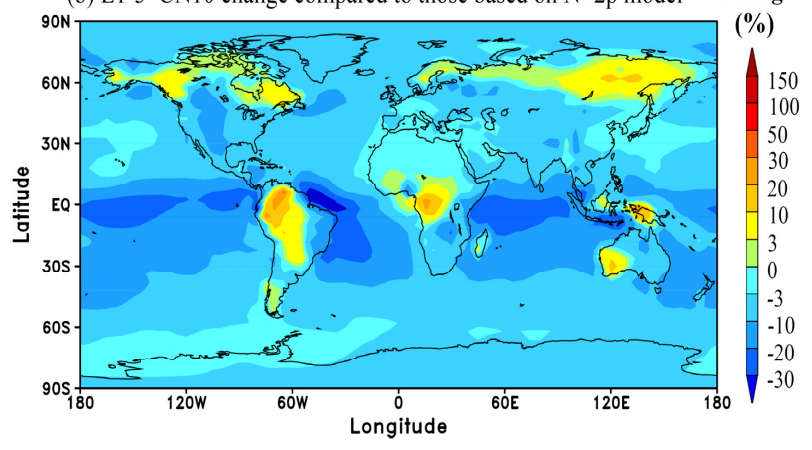

Fig. 8. (a) Horizontal distributions of annual mean number concentrations of condensation nuclei larger than $10 \mathrm{~nm}(\mathrm{CN} 10)$ in the lower boundary layer $(0-0.4 \mathrm{~km})$ simulated with the $N \times 2 \mathrm{p}+\mathrm{A} / \mathrm{C}$ model described in this paper. The observed annual or multiple year averaged CN10 values from 21 sites are also overlapped on the plots for comparison. See text for the sources of the data. (b) Percentage change in $\mathrm{CN} 10$ compared to the case without oxidation aging and LV-SOG condensation (i.e., original $N \times 2 \mathrm{p}$ model).

layers) for the case with LV-SOG condensation, and percentage changes in $\mathrm{CCN} 0.2$ when compared to the case without SOG oxidation aging and LV-SOG condensation. In our model we calculate $\mathrm{CCN}$ concentrations at a given supersaturation from the simulated particle size distributions and compositions, using the scheme of Petters and Kreidenweis (2007). As can be seen from Fig. 10a, annual mean CCN0.2 values in the lower troposphere over major continents generally exceed $\sim 200 \mathrm{~cm}^{-3}$ with the highest values reaching above $1000 \mathrm{~cm}^{-3}$, while those over oceans are generally below $100 \mathrm{~cm}^{-3}$ with the lowest values dipping under $40 \mathrm{~cm}^{-3}$. It is clear from Fig. 10b that SOG oxidation aging and LV-SOG condensation substantially increases annual mean CCN0.2 values in most parts of the lower troposphere, ranging from 5-20\% over a large fraction of oceans and high latitude continents to more than $50 \%$ over some parts of South America, Australia, and Indonesia. The enhancement is relatively lower over southern oceans and over northern pacific. Over the major continents, the enhancement is relatively low $(<\sim 10 \%)$ in the regions of high CCN0.2 values

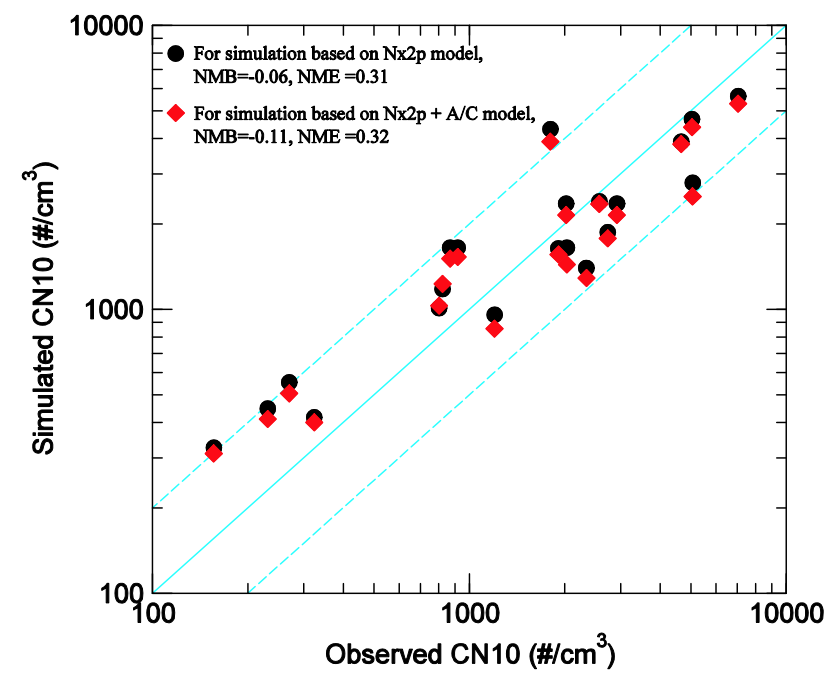

Fig. 9. Comparison of annually averaged number concentrations of CN10 observed at 21 sites shown in Fig. 8a with those simulated with $N \times 2 \mathrm{p}$ and $N \times 2 \mathrm{p}+\mathrm{A} / \mathrm{C}$ SOA formation models. The solid line shows a 1:1 ratio, and the dashed lines show ratios of $2: 1$ and $1: 2$.

$\left(>\sim 450 \mathrm{~cm}^{-3}\right)$ such as the Eastern United States, Eastern Asian, and Europe. The regions of the highest CCN0.2 enhancement (>50\%) include Northwest America, Indonesia, Australia, Southern Africa and America and their associated outflows, where the CCN0.2 values are in the range of several tens to several hundreds per $\mathrm{cm}^{3}$. We also see a slight decrease $(<\sim 5 \%)$ of CCN0.2 in the Middle East and Northern Africa, most likely a result of the reduction of secondary particles transported to these regions (Fig. 8) and the absence of LV-SOG in the area (Fig. 3).

$\mathrm{CCN}$ concentrations are well known to be important for aerosol indirect radiative forcing. Based on the relationship between cloud albedo $(A)$ and $\mathrm{CCN}$ concentration $(N)$ given in Platnick and Twomey (1994) $(\Delta A / A=(1-A) / 3 \times$ $\Delta N / N)$, a $10 \%$ increase in CCN concentrations can lead to $\sim 2 \%$ increase in average cloud albedo (assuming global average A of 0.42, Han et al. (2001). Since clouds on average reflect about $50 \mathrm{~W} \mathrm{~m}^{-2}$ of incoming solar radiation back to space (Hartmann, 1993), a 2\% increase in the average cloud albedo could lead to a radiative forcing of $\sim-1 \mathrm{~W} \mathrm{~m}^{-2}$. Thus, the negative first indirect radiative forcing associated with SOA formation could be well above $0.5 \mathrm{~W} \mathrm{~m}^{-2}$ over major continents and a large fraction of middle latitude oceans in the southern hemisphere. While these estimations are crude, they do indicate the importance of properly representing the SOA formation and its contribution to particle growth and $\mathrm{CCN}$ abundance within global aerosol models. 
(a) L1-14 CCN0.2 based on $\mathrm{N} \times 2 \mathrm{p}+\mathrm{A} / \mathrm{C}$ model
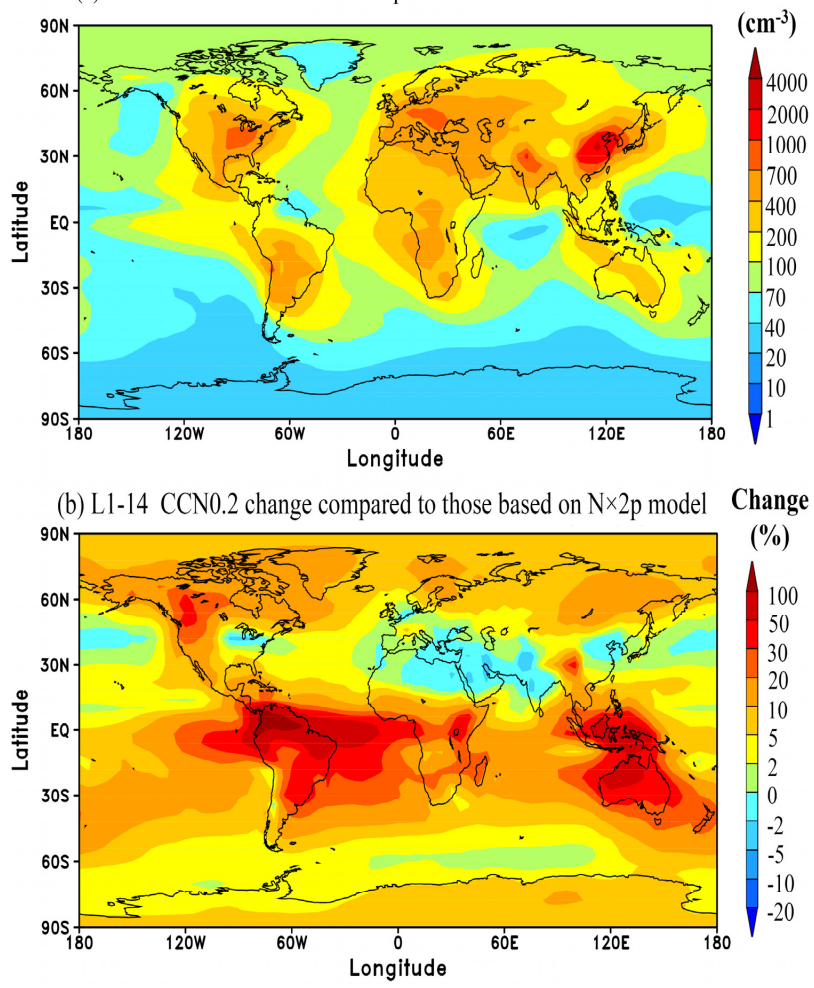

Fig. 10. (a) Horizontal distributions of annual mean number concentrations of cloud condensation nuclei at a water supersaturation ratio of $0.2 \%$ (CCN0.2) in the lower troposphere ( $0-2 \mathrm{~km}$ above surface) simulated with the $N \times 2 \mathrm{p}+\mathrm{A} / \mathrm{C}$ new SOA formation model described in this paper. (b) Percentage change in CCN0.2 compared to the case without oxidation aging and LV-SOG condensation (i.e., original $N \times 2 \mathrm{p}$ model).

\section{Summary and discussion}

The contribution of secondary organic aerosol (SOA) to particle growth, size, and mass is one of the major uncertainties in current regional and global aerosol simulations. The volatility changes of secondary organic gases (SOGs) arising from the aging process as well as the contribution of low volatile SOGs to the condensational growth of secondary particles have been found to be important in recent laboratory and field measurements but are poorly represented in global aerosol models. In this study, we extend the widely used $N \times 2 \mathrm{p}$ SOA formation model so that it can consider the aging process as well as the kinetic condensation of lowvolatile SOGs (i.e., $N \times 2 \mathrm{p}+\mathrm{A} / \mathrm{C}$ ). According to their effective saturation vapor pressure, we group SOGs from biogenic VOC oxidation into two classes: semi-volatile SOG (SV-SOG) and medium-volatile SOG (MV-SOG). Thereafter, we extend the $N \times 2 \mathrm{p}$ model by adding a third component representing low-volatile SOG (LV-SOG) and design a scheme to transfer MV-SOG to SV-SOG and SV-SOG to LV-SOG as a result of oxidation aging. The saturation va- por pressure of this LV-SOG is in the range of $\sim 0.01-3 \mathrm{ppt}$ and is low enough to enable it to directly condense on preexisting particles. The extended SOA formation model has been implemented in a recently developed size-resolved (sectional) global aerosol model GEOS-Chem + APM. The concentration of LV-SOG ([LV-SOG]) is predicted and the cocondensation of $\mathrm{H}_{2} \mathrm{SO}_{4}$ and LV-SOG on size-resolved secondary particles is explicitly simulated, along with the scavenging of these precursors by primary particles.

Our simulations indicate that [LV-SOG] is generally a factor of $\sim 2-20$ higher than $\left[\mathrm{H}_{2} \mathrm{SO}_{4}\right]$ over many parts of the continents and significantly enhance the growth rates of nucleated particles. A comparison of the simulated and observed evolution of particle size distributions in a boreal forest site (Hyytiälä, Finland) clearly shows that the condensation of oxidation aging and LV-SOG is important to bring the simulations close to the observations. With the $N \times 2 \mathrm{p}+\mathrm{A} / \mathrm{C}$ SOA formation scheme, annual mean SOA mass in the boundary layer over the whole globe increases significantly (by a fact of 2-10 in many parts of the boundary layer) and reaches above $0.5 \mu \mathrm{g} / \mathrm{m}^{3}$ in most parts of the main continents. A comparison of simulated SOA mass concentrations with AMS measurements obtained at a number of urban and rural sites indicates that the $N \times 2 \mathrm{p}+\mathrm{A} / \mathrm{C}$ scheme substantially improves the agreement between simulated and observed values. We also find that LV-SOG condensation increases particle surface area, reduces $\left[\mathrm{H}_{2} \mathrm{SO}_{4}\right]$, and thus decreases the formation rates of new particles. As a result, the concentration of condensation nuclei larger than $10 \mathrm{~nm}(\mathrm{CN} 10)$ decreases by $3-30 \%$ in most parts of the lower boundary layer when LV-SOG condensation is included. A comparison of simulated annual mean $\mathrm{CN} 10$ values with the annual or multiple-year averaged $\mathrm{CN} 10$ values observed in 21 surface sites around the globe indicates that both $N \times 2 \mathrm{p}$ and $N \times 2 \mathrm{p}+\mathrm{A} / \mathrm{C}$ schemes appear to be able to capture the observed annual mean $\mathrm{CN} 10$ values within a factor of $\sim 2$. SOG oxidation aging and LV-SOG condensation substantially increase CCN0.2 values in many parts of the lower troposphere, which is significant enough to have important impact on aerosol indirect radiative forcing.

Our study suggests that the aging of VOC oxidation products and their contribution of particle growth could substantially increase $\mathrm{CCN}$ concentrations in the lower troposphere and enhance aerosol indirect radiative forcing. In view of the strong dependence of aerosol indirect radiative forcing on CCN concentrations, our study highlights the importance for global aerosol models to explicitly take into account and reduce uncertainty associated with the oxidation aging of SOGs and their contribution of particle growth. Further research is needed to reduce the uncertainty in SOG oxidation aging rates, characterize the contributions of the aging of anthropogenic VOCs and oceanic VOC emissions to the LVSOG concentration, improve the representation of SOGs and size-resolved SOA, as well as validate the model predictions with more detailed measurements. 
Acknowledgements. The author thanks Gan Luo (University at Albany) for assistance in running the GEOS-Chem model. The GEOS-Chem model is managed by the Atmospheric Chemistry Modeling Group at Harvard University with support from the NASA Atmospheric Chemistry Modeling and Analysis Program. The author thanks Markku Kulmala (University of Helsinki) for making their particle size distribution data available via CREATE Aerosol Database at NILU. This study is supported by NASA under grant NNX08AK48G and NSF under grant 0942106.

Edited by: J. H. Seinfeld

\section{References}

Arnold, S. R., Spracklen, D. V., Williams, J., Yassaa, N., Sciare, J., Bonsang, B., Gros, V., Peeken, I., Lewis, A. C., Alvain, S., and Moulin, C.: Evaluation of the global oceanic isoprene source and its impacts on marine organic carbon aerosol, Atmos. Chem. Phys., 9, 1253-1262, doi:10.5194/acp-9-1253-2009, 2009.

Aumont, B., Szopa, S., and Madronich, S.: Modelling the evolution of organic carbon during its gas-phase tropospheric oxidation: development of an explicit model based on a self generating approach, Atmos. Chem. Phys., 5, 2497-2517, doi:10.5194/acp-52497-2005, 2005.

Bey, I., Jacob, D., Yantosca, R., Logan, J., Field, B., Fiore, A., Li, Q., Liu, H., Mickley, L., and Schultz, M.: Global modeling of tropospheric chemistry with assimilated meteorology: Model description and evaluation, J. Geophys. Res., 106, 23073-23096, 2001.

Bilde, M. and Pandis, S. N.: Evaporation rates and vapor pressures of individual aerosol species formed in the atmospheric oxidation of $\alpha$ - and $\beta$-pinene, Environ. Sci. Technol., 35, 3344-3349, 2001.

Bond, T. C., Bhardwaj, E., Dong, R., Jogani, R., Jung, S., Roden, C., Streets, D. G., and Trautmann, N. M.: Historical emissions of black and organic carbon aerosol from energy related combustion, 1850-2000, Global Biogeochem. Cy., 21, GB2018, doi:10.1029/2006GB002840, 2007.

Camredon, M., Aumont, B., Lee-Taylor, J., and Madronich, S.: The SOA/VOC/NO $\mathrm{N}_{\mathrm{x}}$ system: an explicit model of secondary organic aerosol formation, Atmos. Chem. Phys., 7, 5599-5610, doi:10.5194/acp-7-5599-2007, 2007.

Carlton, A. G., Bhave, P. V., Napelenok, S. L., Edney, E. O., Sarwar, G., Pinder, R. W., Pouliot, G. A., and Houyoux, M.: Model representation of secondary organic aerosol in CMAQv4.7, Environ. Sci. Technol., 44(22), 8553-8560, 2010.

Chattopadhyay, S. and Ziemann, P. J.: Vapor Pressures of Unsubstituted and Substituted Monocarboxylic and Dicarboxylic Acids Measured Using an Improved Thermal Desorption Particle Beam Mass Spectrometry Method, Aerosol Sci. Technol., 39, 10851100, 2005.

Chen, J., Mao, H. T., Talbot, R. W., and Griffin, R. J.: Application of the CACM and MPMPO modules using the CMAQ model for the eastern United States, J. Geophys. Res., 111, D23S25, doi:10.1029/2006JD007603, 2006.

Chung, S. H. and Seinfeld, J. H.: Global distribution and climate forcing of carbonaceous aerosols, J. Geophys. Res., 107, 4407, doi:10.1029/2001JD001397, 2002.
Dal Maso, M., Hyvärinen, A., Komppula, M., Tunved, P., Kerminen, V. M., Lihavainen, H., Viisanen, Y., Hansson, H. C., and Kulmala, M.: Annual and interannual variation in boreal forest aerosol particle number and volume concentration and their connection to particle formation, Tellus, 60B, 495-508, 2008.

Donahue, N. M., Robinson, A. L., Stanier, C. O., and Pandis, S. N.: Coupled partitioning, dilution, and chemical aging of semivolatile organics, Environ. Sci. Technol., 40, 2635-2643, 2006.

Ehn, M., Petäjä, T., Aufmhoff, H., Aalto, P., Hmeri, K., Arnold, F., Laaksonen, A., and Kulmala, M.: Hygroscopic properties of ultrafine aerosol particles in the boreal forest: diurnal variation, solubility and the influence of sulfuric acid, Atmos. Chem. Phys., 7, 211-222, doi:10.5194/acp-7-211-2007, 2007.

Epstein, S., Riipinen, I., and Donahue, A. M.: A semiempirical correlation between enthalpy of vaporization and saturation concentration for organic aerosol, Environ. Sci. Technol., 44, 743-748, 2010.

Evans, M. J. and Jacob, D. J.: Impact of new laboratory studies of $\mathrm{N}_{2} \mathrm{O}_{5}$ hydrolysis on global model budgets of tropospheric nitrogen oxides, ozone, and OH, Geophys. Res. Lett., 32, L09813, doi:10.1029/2005GL022469, 2005.

Gantt, B., Meskhidze, N., and Kamykowski, D.: A new physically-based quantification of marine isoprene and primary organic aerosol emissions, Atmos. Chem. Phys., 9, 4915-4927, doi:10.5194/acp-9-4915-2009, 2009.

Griffin, R. J., Cocker III, D. R., Flagan, R. C., and Seinfeld, J. H.: Organic aerosol formation from the oxidation of biogenic hydrocarbons, J. Geophys. Res., 104, 3555-3567, 1999.

Griffin, R. J., Dabdub, D., and Seinfeld, J. H.: Secondary organic aerosol. I. Atmospheric chemical mechanism for production of molecular constituents, J. Geophys. Res., 107, 4332, doi:10.1029/2001JD000541, 2002.

Griffin, R. J., Nguyen, K., Dabdub, D., and Seinfeld, J. H.: A coupled hydrophobic-hydrophilic model for predicting secondary organic aerosol formation, J. Atmos. Chem., 44, 171-190, 2003.

Guenther, A., Karl, T., Harley, P., Wiedinmyer, C., Palmer, P. I., and Geron, C.: Estimates of global terrestrial isoprene emissions using MEGAN (Model of Emissions of Gases and Aerosols from Nature), Atmos. Chem. Phys., 6, 3181-3210, doi:10.5194/acp-63181-2006, 2006.

Hallquist, M., Wenger, J. C., Baltensperger, U., Rudich, Y., Simpson, D., Claeys, M., Dommen, J., Donahue, N. M., George, C., Goldstein, A. H., Hamilton, J. F., Herrmann, H., Hoffmann, T., Iinuma, Y., Jang, M., Jenkin, M. E., Jimenez, J. L., Kiendler-Scharr, A., Maenhaut, W., McFiggans, G., Mentel, Th. F., Monod, A., Prévôt, A. S. H., Seinfeld, J. H., Surratt, J. D., Szmigielski, R., and Wildt, J.: The formation, properties and impact of secondary organic aerosol: current and emerging issues, Atmos. Chem. Phys., 9, 5155-5236, doi:10.5194/acp-95155-2009, 2009.

Han, Q., Rossow, W. B., Chou, J., and Welch, R. M.: Global survey of the relationships of cloud albedo and liquid water path with droplet size using ISCCP, J. Climate, 11, 1516-1528, 1998.

Hartmann, D. L.: Radiative effects of clouds on Earth's climate, in: Aerosol-Cloud-Climate Interactions, edited by: Bobbs, P. V., Academic Press, Harcourt Brace \& Company, New York, 1993.

Heald, C. L., Jacob, D. J., Park, R. J., Russell, L. M., Huebert, B. J., Seinfeld, J. H., Liao, H., and Weber, R. J.: 
A large organic aerosol source in the free troposphere missing from current models, Geophys. Res. Lett., 32, L18809, doi:10.1029/2005GL023831, 2005.

Henze, D. K. and Seinfeld, J. H.: Global secondary organic aerosol from isoprene oxidation, Geophys. Res. Lett., 33, L09812, doi:10.1029/2006GL025976, 2006.

Henze, D. K., Seinfeld, J. H., Ng, N. L., Kroll, J. H., Fu, T.-M., Jacob, D. J., and Heald, C. L.: Global modeling of secondary organic aerosol formation from aromatic hydrocarbons: highvs. low-yield pathways, Atmos. Chem. Phys., 8, 2405-2420, doi:10.5194/acp-8-2405-2008, 2008.

Jenkin, M. E.: Modelling the formation and composition of secondary organic aerosol from $\alpha$ - and $\beta$-pinene ozonolysis using MCM v3, Atmos. Chem. Phys., 4, 1741-1757, doi:10.5194/acp4-1741-2004, 2004.

Jimenez, J. L., Canagaratna, M. R., Donahue, N. M., Prevot, A. S. H., Zhang, Q., Kroll, J. H., DeCarlo, P. F., Allan, J. D., Coe, H., Ng, N. L., Aiken, A. C., Docherty, K. D., Ulbrich, I. M., Grieshop, A. P., Robinson, A. L., Duplissy, J., Smith, J. D., Wilson, K. R., Lanz, V. A., Hueglin, C., Sun, Y. L., Tian, J., Laaksonen, A., Raatikainen, T., Rautiainen, J., Vaattovaara, P., Ehn, M., Kulmala, M., Tomlinson, J. M., Collins, D. R., Cubison, M. J., Dunlea, E. J., Huffman, J. A., Onasch, T. B., Alfarra, M. R., Williams, P. I., Bower, K., Kondo, Y., Schneider, J., Drewnick, F., Borrmann, S., Weimer, S., Demerjian, K., Salcedo, D., Cottrell, L., Griffin, R., Takami, A., Miyoshi, T., Hatakeyama, S., Shimono, A., Sun, J. Y, Zhang, Y. M., Dzepina, K., Kimmel, J. R., Sueper, D., Jayne, J. T., Herndon, S. C., Trimborn, A. M., Williams, L. R., Wood, E. C., Kolb, C. E., Middlebrook, A. M., Baltensperger, U., and Worsnop, D. R.: Evolution of Organic Aerosols in the Atmosphere, Science, 326, 1525, doi:10.1126/science.1180353, 2009.

Johnson, D., Jenkin, M. E., Wirtz, K., and Martin-Reviejo, M.: Simulating the formation of secondary organic aerosol from photooxidation of toluene, Environ. Chem., 1, 150-165, 2004.

Johnson, D., Utembe, S. R., and Jenkin, M. E.: Simulating the detailed chemical composition of secondary organic aerosol formed on a regional scale during the TORCH 2003 campaign in the southern UK, Atmos. Chem. Phys., 6, 419-431, doi:10.5194/acp-6-419-2006, 2006.

Kivekäs, N., Sun, J., Zhan, M., Kerminen, V.-M., Hyvärinen, A., Komppula, M., Viisanen, Y., Hong, N., Zhang, Y., Kulmala, M., Zhang, X.-C., Deli-Geer, and Lihavainen, H.: Long term particle size distribution measurements at Mount Waliguan, a highaltitude site in inland China, Atmos. Chem. Phys., 9, 5461-5474, doi:10.5194/acp-9-5461-2009, 2009.

Komppula, M., Lihavainen, H., Hyvärinen, A.-P., Kerminen, V.-M., Panwar, T. S., Sharma, V. P., and Viisanen, Y.: Physical properties of aerosol particles at a Himalayan background site in India, J. Geophys. Res., 114, D12202, doi:10.1029/2008JD011007, 2009.

Kroll, J. H. and Seinfeld, J. H.: Chemistry of secondary organic aerosol: Formation and evolution of low-volatility organics in the atmosphere, Atmos. Environ., 42, 3593-3624, 2008.

Kroll, J. H., Ng, N. L., Murphy, S. M., Flagan, R. C., and Seinfeld, J. H.: Secondary organic aerosol formation from isoprene photooxidation, Environ. Sci. Technol., 40, 1869-1877, 2006.

Kuang, C., Riipinen, I., Sihto, S.-L., Kulmala, M., McCormick, A. V., and McMurry, P. H.: An improved criterion for new particle formation in diverse atmospheric environments, Atmos. Chem. Phys., 10, 8469-8480, doi:10.5194/acp-10-8469-2010, 2010.

Kulmala, M., Vehkamäki, H., Petäjä, T., Dal Maso, M., Lauri, A., Kerminen, V.-M., Birmili, W., and McMurry, P.: Formation and growth rates of ultrafine atmospheric particles: A review of observations, J. Aerosol Sci., 35, 143-176, 2004.

Laakso, L., Anttila, T., Lehtinen, K. E. J., Aalto, P. P., Kulmala, M., Hõrrak, U., Paatero, J., Hanke, M., and Arnold, F.: Kinetic nucleation and ions in boreal forest particle formation events, Atmos. Chem. Phys., 4, 2353-2366, doi:10.5194/acp-4-2353-2004, 2004.

Laakso, L., Laakso, H., Aalto, P. P., Keronen, P., Petäjä, T., Nieminen, T., Pohja, T., Siivola, E., Kulmala, M., Kgabi, N., Molefe, M., Mabaso, D., Phalatse, D., Pienaar, K., and Kerminen, V.-M.: Basic characteristics of atmospheric particles, trace gases and meteorology in a relatively clean Southern African Savannah environment, Atmos. Chem. Phys., 8, 4823-4839, doi:10.5194/acp-8-4823-2008, 2008.

Laaksonen, A., Kulmala, M., O’Dowd, C. D., Joutsensaari, J., Vaattovaara, P., Mikkonen, S., Lehtinen, K. E. J., Sogacheva, L., Dal Maso, M., Aalto, P., Petäjä, T., Sogachev, A., Yoon, Y. J., Lihavainen, H., Nilsson, D., Facchini, M. C., Cavalli, F., Fuzzi, S., Hoffmann, T., Arnold, F., Hanke, M., Sellegri, K., Umann, B., Junkermann, W., Coe, H., Allan, J. D., Alfarra, M. R., Worsnop, D. R., Riekkola, M. -L., Hyötyläinen, T., and Viisanen, Y.: The role of VOC oxidation products in continental new particle formation, Atmos. Chem. Phys., 8, 2657-2665, doi:10.5194/acp-82657-2008, 2008.

Liao, H., Henze, D. K., Seinfeld, J. H., Wu, S., and Mickley, L. J.: Biogenic secondary organic aerosol over the United States: Comparison of climatological simulations with observations, J. Geophys. Res., 112, D06201, doi:10.1029/2006JD007813, 2007.

Luo, G. and Yu, F.: A numerical evaluation of global oceanic emissions of $\alpha$-pinene and isoprene, Atmos. Chem. Phys., 10, 20072015, doi:10.5194/acp-10-2007-2010, 2010.

Martin, R. V., Jacob, D. J., Yantosca, R. M., Chin, M., and Ginoux, P.: Global and regional decreases in tropospheric oxidants from photochemical effects of aerosols, J. Geophys. Res., 108, 4097, doi:10.1029/2002JD002622, 2003.

Odum, J. R., Hoffmann, T., Bowman, F., Collins, D., Flagan, R. C., and Seinfeld, J. H.: Gas/particle partitioning and secondary organic aerosol yields, Environ. Sci. Technol., 30, 2580-2585, 1996.

Offenberg, J. H., Kleindienst, T. E., Jaoui, M., Lewandowski, M., and Edney, E. O.: Thermal properties of secondary organic aerosols, Geophys. Res. Lett., 33, L03816, doi:03810.01029/02005GL024623, 2006.

Pankow, J. F.: An absorption model of the gas/aerosol partitioning involved in the formation of secondary organic aerosol, Atmos. Environ., 28(6), 189-193, 1994.

Pankow, J. F. and Asher, W. E.: SIMPOL.1: a simple group contribution method for predicting vapor pressures and enthalpies of vaporization of multifunctional organic compounds, Atmos. Chem. Phys., 8, 2773-2796, doi:10.5194/acp-8-27732008, 2008.

Pankow, J. F. and Barsanti, K. C.: The carbon number-polarity grid: A means to manage the complexity of the mix of organic compounds when modeling atmospheric organic particulate matter, Atmos. Environ., 43, 2829-2835, 2009. 
Pathak, R. K., Presto, A. A., Lane, T. E., Stanier, C. O., Donahue, N. M., and Pandis, S. N.: Ozonolysis of a-pinene: parameterization of secondary organic aerosol mass fraction, Atmos. Chem. Phys., 7, 3811-3821, doi:10.5194/acp-7-3811-2007, 2007.

Park, R. J., Jacob, D. J., Field, B. D., Yantosca, R. M., and Chin, M.: Natural and transboundary pollution influences on sulfate-nitrate-ammonium aerosols in the United States: Implications for policy, J. Geophys. Res., 109, D15204, doi:10.1029/2003JD004473, 2004.

Petters, M. D. and Kreidenweis, S. M.: A single parameter representation of hygroscopic growth and cloud condensation nucleus activity, Atmos. Chem. Phys., 7, 1961-1971, doi:10.5194/acp-71961-2007, 2007.

Platnick, S. and Twomey, S.: Determining the susceptibility of cloud albedo to changes in droplet concentration with the advanced very high resolution radiometer, J. Appl. Meteorol., 33, 334-347, 1994.

Pun, B. K., Griffin, R. J., Seigneur, C., and Seinfeld, J. H.: Secondary organic aerosol. II. Thermodynamic model for gas/particle partitioning of molecular constituents, J. Geophys. Res., 107, 4333, doi:10.1029/2001JD000542, 2002.

Pye, H. O. T. and Seinfeld, J. H.: A global perspective on aerosol from low-volatility organic compounds, Atmos. Chem. Phys., 10, 4377-4401, doi:10.5194/acp-10-4377-2010, 2010.

Robinson, A. L., Donahue, N. M., Shrivastava, M. K., Weitkamp, E. A., Sage, A. M., Grieshop, A. P., Lane, T. E., Pierce, J. R., and Pandis, S. N.: Rethinking Organic Aerosols: Semivolatile emissions and photochemical aging, Science, 315, 1259-1262, 2007.

Rudich, Y., Donahue, N. M., and Mentel, T. F.: Aging of organic aerosol: Bridging the gap between laboratory and field studies, Annu. Rev. Phys. Chem., 58, 321-352, 2007.

Saathoff, H., Naumann, K.-H., Möhler, O., Jonsson, Å. M., Hallquist, M., Kiendler-Scharr, A., Mentel, Th. F., Tillmann, R., and Schurath, U.: Temperature dependence of yields of secondary organic aerosols from the ozonolysis of $\alpha$-pinene and limonene, Atmos. Chem. Phys., 9, 1551-1577, doi:10.5194/acp-9-15512009, 2009.

Seinfeld, J. H. and Pankow, J. F.: Organic atmospheric particulate material, Annu. Rev. Phys. Chem., 54, 121-140, 2003.

Stanier, C. O., Pathak, R. K., and Pandis, S. N.: Measurements of the volatility of aerosols from $\alpha$-piniene ozonolysis, Environ. Sci. Technol., 41, 2756-2763, 2007.

Suni, T., Kulmala, M., Hirsikko, A., Bergman, T., Laakso, L., Aalto, P. P., Leuning, R., Cleugh, H., Zegelin, S., Hughes, D., van Gorsel, E., Kitchen, M., Vana, M., Hõrrak, U., Mirme, S., Mirme, A., Sevanto, S., Twining, J., and Tadros, C.: Formation and characteristics of ions and charged aerosol particles in a native Australian Eucalypt forest, Atmos. Chem. Phys., 8, 129-139, doi:10.5194/acp-8-129-2008, 2008.

Svendby, T. M., Lazaridis, M., and Torseth, K.: Temperature dependent secondary organic aerosol formation from terpenes and aromatics, J. Atmos. Chem., 59, 25-46, 2008.

Tsigaridis, K. and Kanakidou, M.: Global modelling of secondary organic aerosol in the troposphere: a sensitivity analysis, Atmos. Chem. Phys., 3, 1849-1869, doi:10.5194/acp-3-1849-2003, 2003.

Venzac, H., Sellegri, K., Laj, P., Villani, P., Bonasoni, P., Marinoni, A., Cristofanelli, P., Calzolari, F., Fuzzi, S., Decesari, S.,
Facchini, M. C., Vuillermoz, E., and Verza, G. P.: High frequency new particle formation in the Himalayas, P. Natl. Acad. Sci. USA, 105, 15666-15671, 2008.

Volkamer, R., Jimenez, J. L., Martini, F. S., Dzepina, K., Zhang, Q., Salcedo, D., Molina, L. T., Worsnop, D. R., and Molina, M. J.: Secondary organic aerosol formation from anthropogenic air pollution: Rapid and higher than expected, Geophys. Res. Lett., 33, L17811, doi:10.1029/2006GL026899, 2006.

Wang, L., Khalizov, A. F., Zheng, J., Xu, W., Lal, V., Ma, Y., and Zhang, R.: Atmospheric nanoparticles formed from heterogeneous reactions of organics, Nature Geosci., 3, 238-242, doi:10.1038/ngeo778, 2010.

Yassaa, N., Peeken, I., Zöllner, E., Bluhm, K., Arnold, S., Spracklen, D., and Williams, J.: Evidence for marine production of monoterpenes, Environ. Chem., 5, 391-401, doi:10.1071/EN08047, 2008.

Yu, F.: From molecular clusters to nanoparticles: second-generation ion-mediated nucleation model, Atmos. Chem. Phys., 6, 51935211, doi:10.5194/acp-6-5193-2006, 2006.

Yu, F.: Ion-mediated nucleation in the atmosphere: Key controlling parameters, implications, and look-up table, J. Geophy. Res., 115, D03206, doi:10.1029/2009JD012630, 2010.

Yu, F. and Luo, G.: Simulation of particle size distribution with a global aerosol model: contribution of nucleation to aerosol and CCN number concentrations, Atmos. Chem. Phys., 9, 76917710, doi:10.5194/acp-9-7691-2009, 2009.

Yu, F. and Luo, G.: Oceanic Dimethyl Sulfide Emission and New Particle Formation around the Coast of Antarctica: A Modeling Study of Seasonal Variations and Comparison with Measurements, Atmosphere, 1, 34-50, doi:10.3390/atmos1010034, 2010.

Yu, F. and Turco, R.: Case studies of particle formation events observed in boreal forests: implications for nucleation mechanisms, Atmos. Chem. Phys., 8, 6085-6102, doi:10.5194/acp-86085-2008, 2008.

Yu, F., Wang, Z., Luo, G., and Turco, R.: Ion-mediated nucleation as an important global source of tropospheric aerosols, Atmos. Chem. Phys., 8, 2537-2554, doi:10.5194/acp-8-2537-2008, 2008.

Yu, F., Luo, G., Bates, T., Anderson, B., Clarke, A., Kapustin, V., Yantosca, R., Wang, Y., and Wu, S.: Spatial distributions of particle number concentrations in the global troposphere: Simulations, observations, and implications for nucleation mechanisms, J. Geophys. Res., 115, D17205, doi:10.1029/2009JD013473, 2010.

Zhang, Q., Jimenez, J. L., Canagaratna, M. R., Allan, J. D., Coe, H., Ulbrich, I., Alfarra, M. R., Takami, A., Middlebrook, A. M., Sun, Y. L., Dzepina, K., Dunlea, E., Docherty, K., DeCarlo, P. F., Salcedo, D., Onasch, T., Jayne, J. T., Miyoshi, T., Shimono, A., Hatakeyama, S., Takegawa, N., Kondo, Y., Schneider, J., Drewnick, F., Weimer, S., Demerjian, K., Williams, P., Bower, K., Bahreini, R., Cotrell, L., Griffin, R. J., Rautiainen, J., Sun, J. Y., Zhang, Y. M., and Worsnop, D. R.: Ubiquity and dominance of oxygenated species in organic aerosols in anthropogenicallyinfluenced Northern Hemisphere midlatitudes, Geophys. Res. Lett., 34, L13801, doi:10.1029/2007GL029979, 2007.

Zhang, Q., Streets, D. G., Carmichael, G. R., He, K. B., Huo, H., Kannari, A., Klimont, Z., Park, I. S., Reddy, S., Fu, J. S., Chen, D., Duan, L., Lei, Y., Wang, L. T., and Yao, Z. L.: Asian emissions in 2006 for the NASA INTEX-B mission, Atmos. Chem. 
Phys., 9, 5131-5153, doi:10.5194/acp-9-5131-2009, 2009.

Zhang, Y., Pun, B., Vijayaraghavan, K., Wu, S. Y., Seigneur, C., Pandis, S. N., Jacobson, M. Z., Nenes, A., and Seinfeld, J. H.: Development and application of the model of aerosol dynamics, reaction, ionization, and dissolution (MADRID), J. Geophy. Res., 109, D01202, doi:10.1029/2003JD003501, 2004.
Ziemba, L. D., Griffin, R. J., and Talbot, R. W.: Observations of elevated particle number concentration events at a rural site in New England, J. Geophys. Res., 111, D23S34, doi:10.1029/2006JD007607, 2006. 